\title{
Laser pyrolysis in papers and patents
}

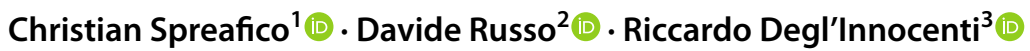

Received: 16 November 2020 / Accepted: 25 June 2021 / Published online: 1 August 2021

(c) The Author(s) 2021

\begin{abstract}
This paper presents a critical review of laser pyrolysis. Although this technology is almost 60 years old, in literature many researchers, both from academia and industry, are still developing and improving it. On the contrary industrial applications are struggling to take off, if not in very restricted areas, although the technology has undoubted advantages that justify future development. The aim of this work consists in analysing a representative pool of scientific papers (230) and patents (121), from the last 20 years, to have an overview about the evolution of the method and try to understand the efforts spent to improve this technology effectively in academia and in industry. This study is important to provide a complete review about the argument, still missing in the literature. The objective is to provide an overview sufficiently broad and representative in the sources and to capture all the main ways in which laser pyrolysis has been used and with what distribution. The main focuses of the study are the analyses of the functions carried out by laser technologies, the application fields, and the types of used laser (i.e. models, power and fluence). Among the main results, the study showed that the main use of laser pyrolysis is to produce nanoparticles and coatings, the main materials worked by laser pyrolysis are silicon and carbon dioxide and the main searched properties in the products of laser pyrolysis are catalysts activity and electrical conductivity. $\mathrm{CO}_{2}$ lasers are the most used and the have high versatility compared to others. In conclusion, the study showed that laser pyrolysis is a consolidated technology within its main application fields (nanoparticles and coatings) for several years. Within this context, the technology has been developed on very different sizes and processes, obtaining a very wide range of results. Finally, these results may also have stimulated new areas of experimentation that emerged mainly in recent years and which concern biomedical applications, additive manufacturing, and waste disposal.
\end{abstract}

\section{Graphical abstract}
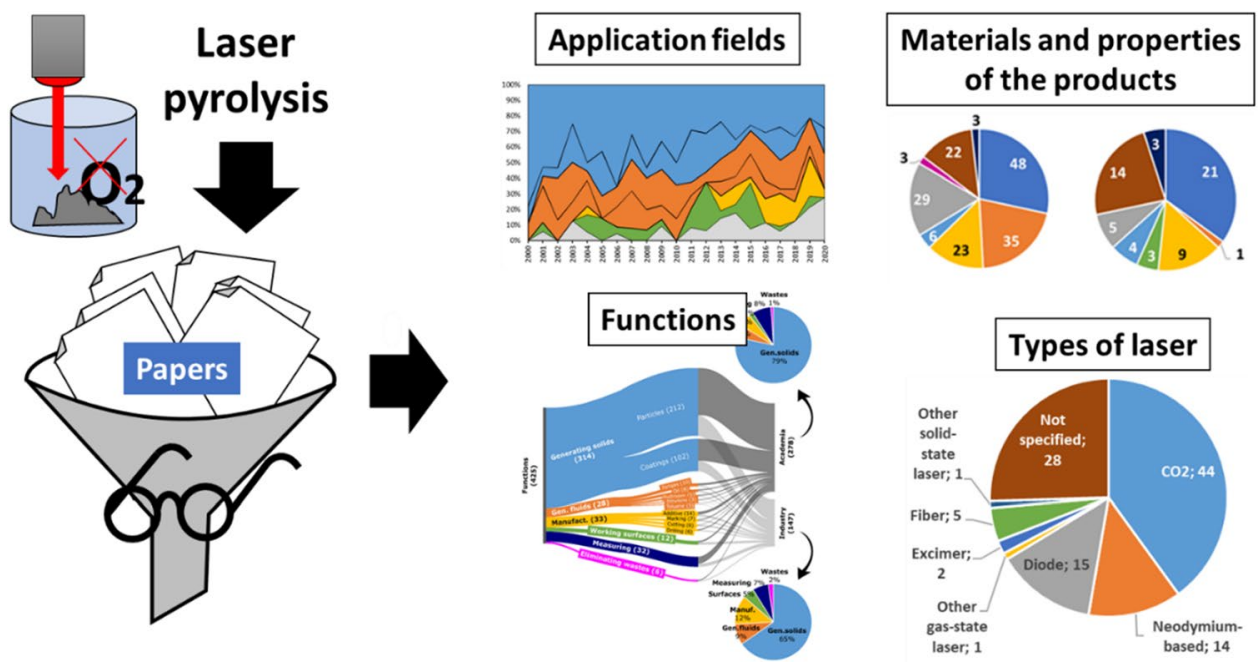

Keywords Pyrolysis · Laser pyrolysis · Bibliometric analysis · Patents

Extended author information available on the last page of the article 


\section{Introduction}

Laser pyrolysis is a technology known at least since the sixties (Folmer \& Azarraga, 1969; Karn et al., 1967), although still today it is considered by several researchers (Gao et al., 2019; Koshida \& Nakamura, 2019; Weyermann, 2019) as an emerging technology both in its most well-known fields of application and in the frontier research. Laser pyrolysis exploits a laser beam to provide the energy necessary for the pyrolysis reaction of a solid, liquid, or gaseous reagent inside a reactor in which there is a controlled and oxygen-free atmosphere. The goal is to obtain the cleavage and subsequent recombination of the chemical bonds of the reactants to generate products of different materials. A field where it is particularly known is the generation of nanopowders consisting of silicon and metal oxides or noble metals starting from a gaseous precursor (Kim et al., 2019a, 2019b).

Several parameters can be considered to describe laser pyrolysis plants from a technological point of view. The most important are the type of laser and the setting parameters (i.e. pulse frequency, diameter of the nozzle, distance between the nozzle and the material to be treated by the laser, focal position and length, type and pressure of auxiliary gas) that are necessary to determine the types of processed materials. Some reasons are the different absorption coefficients, which depends by the electromagnetic wavelength of the laser, the power of the plant, the heating rate, the reaction temperatures, the processed flow rate, and the generated products.

If compared with other types of pyrolysis (e.g. plasma, microwave, fixed and fluidized bed, with hot sand), from the point of view of the chemical characterization of the reaction, laser pyrolysis could ideally be considered as an alternative for flash and fast pyrolysis. In fact, the heating rates and the temperatures of reaction are high, the generation of gaseous products is predominant, and the reaction occurs in a few seconds. However, laser pyrolysis is not concurred to these technologies within their typical fields of application, such as waste disposal or electricity generation (Bridgwater, 2012; Lewandowski et al., 2019; Sharuddin et al., 2016).

Given the very high precision of the interaction with the raw material, laser pyrolysis is mainly exploited when a very selective heat transmission is required, such as the treatment of the nano powders and the produce sintered coatings. In this field, laser pyrolysis allows to eliminate some onerous stages of the process, such as the washing and drying steps, which are instead necessary in competing wet-chemical methods. In addition, these last are less performing in terms of heating transfer (Kim et al., 2014). For these reasons, in this field, laser pyrolysis is progressively stealing the market segment to other methods (Wang et al., 2017 and Tangermann-Gerk et al., 2016). Its main advantages are the high fluence and the continuous heat transfer, allowing a rapid synthesis processes up to $1 \mathrm{~kg} / \mathrm{h}$ in industrial plants (Leconte et al., 2007). A recent trend, however, is to reduce the vacuum degree and its complication up to the realization of the so-called laser coatings (Simoni et al., 2021).

The laser pyrolysis can also ensure a high purity of the materials produced since by managing to confine the heat source and consequently the reaction zone away from the walls of the reactor, contaminations are reduced. In addition, the heat concentration favours a very high thermal gradient. For this reason, the dissociation and reassociation of the molecules of the reactants are extended to a greater number of different chemical bonds to produce generate a wider range of different products and materials (Wang et al., 2017). Compared to microwaves and plasma pyrolysis, in laser pyrolysis the heat transmission can be better controlled, by ensuring both steeper heating ramps and higher precision (Bridgwater, 2012). Finally, based on pure bibliographic studies and theoretical evolutive models, laser pyrolysis emerged to be more advanced than competing pyrolysis technologies (Russo et al., 2019; Spreafico et al., 2021).

Therefore, by virtue of these advantages, the hypothesis of this study is that laser pyrolysis, thanks to its peculiarities, in the near future, may be exploited in various fields, despite the long period of incubation within the most peculiar ones. For this reason, investigating the current state of development of the technology in the literature can be more strategic than analysing commercial applications, to see the development directions still experimental. However, today, in literature an extensive review about laser pyrolysis do not seem to exist. Only some contributions compare pros and cons of laser pyrolysis with other alternative technologies, also not involving pyrolysis and used in the same application field (e.g. Jamkhande et al., 2019; Ealias and Saravanakumar, 2017). Such studies can be useful to select a technology to be used in a specific application field according to some parameters about the features of the obtained products (e.g. purity, mechanical strength, electrical conductivity) and the production process (e.g. time, flow and required energy). Finally, only one type of laser (e.g. $\mathrm{CO}_{2}$ ) and with a determined power is generally considered, while the field of application are few and too specific.

To fill this gap, this article is the first to propose an extensive review on laser pyrolysis, analysing and classifying many documents from the reference literature. Both scientific papers and patent were included to provide the reader with a double perspective related to both the academic and the industrial contexts. The considered parameters of laser pyrolysis are: 
- Application fields in which the same technology or its products can be used, e.g. electronics, medical, chemistry.

- Functions, i.e. the operations that laser pyrolysis can perform, e.g. obtaining particles, depositing a coating, working a surface.

- Technology: types of used laser and their performances.

The analysis is based on bibliometric indicators, such as the number of the sources and the time trend of the publications, to provide a quantitative indication. The counting of the documents in the different classes was carried out in a purely manual modality, considering only what is explicitly reported within the analysed documents. This review aims to provide an overview on the real current diffusion of laser pyrolysis, and its future potential both in academia and in industry.

This study introduces some elements of novelty compared to the previous reviews in the literature.

- The number of considered documents passing from few units to hundreds.

- The provided classification by application fields and technologies is not entirely new. However, the studies that have already adopted this classification have not linked the two aspects, while this review provide a new perspective, describing exactly how a technology works to fulfil a purpose typical of an application field.

- In addition, the novel classification by function has been introduced, which has no equivalent in the literature. In this study, the function is used as a linkage between the technology and the application field, as experimented in Russo et al. (2020).

- The analysis at the bibliographic level is a novelty for this topic, since the other reviews propose analysis exclusively focused on the operational parameters.

- Finally, the review about the future emerging application fields is the last element of novelty since previous review mainly compare the current and most diffused applications of laser pyrolysis.

This study has a clear practical significance for researchers and professional involved in laser pyrolysis or interested in the all the fields where the technology can be applied. The mapping offered for the operating parameters of the laser according to the objectives (functions and fields of application) is sufficiently broad and complete to serve as a knowledge base for an initial technological assessment. The professional interested in selecting the most suitable type of laser can benefit from the presentation of the technical parameters and the discussion of the main pros and cons of each technology. The detailed presentation of the many alternative methods of use, especially the most innovative ones, can instead be useful to highlight the new directions of development of the technology. A researcher can take advantage of understanding at what level the research has gone into the various fields as well as learning who is working on the topic and how. An entrepreneur can instead be stimulated to invest in the technology in the most innovative areas, especially by discovering the many presented scientific studies and patents, which are not yet developed.

The knowledge gap that this article aims to fill concerns the lack of an overall broad comparison on the topic of laser pyrolysis, which shows its applications over the years. In the scientific literature, a comparison showing the relative distribution of the uses of this technology is missing, as is that of the different types of exploited lasers, while both these aspects are addressed in this study. The bibliographic analysis conducted on scientific articles brings new evidence, since the few reviews on the subject do not provide a valid overview since they analyse very few contributions. The knowledge emerging from the analysis of the patents is instead completely new in this field, providing an idea about how industry is working in this field, also in comparison with academia.

\section{Research methodology}

The documents considered in this review were collected and analysed through a multi-step procedure based on an extensive manual review. Although contributions about laser pyrolysis could be heterogeneously disseminated among scientific articles, conference proceedings, books, technical catalogues, and patents, in this review, only the first and the last ones were considered due to their reliability and completeness. The articles have been considered because they should provide a truthful and non-commercial data presentation perspective and they are usually reviewed through a rigorous peer-review process. For this reason, only those published in international journals, indexed in the main scientific databases, were selected. While patents were considered for their linkage with the industrial field, albeit the revision process is less rigorous than articles from the scientific point of view.

The articles were searched within the SCOPUS database, while the patents in Fampat database developed by Questel, using the same query, unless the software syntax changes, within the title, abstract and keywords of the documents. The query was (pyrol* AND laser*), where the truncation operator is "* in SCOPUS and "+" in Fampat. Among the obtained documents, only those published since 2000 (i.e. publication date for papers and priority date for patents) have been collected, using the SCOPUS and Fampat automatic filters. This choice was arbitrarily decided to limit the pool 
of documents to be analysed. These queries provide 2168 articles and 234 patents.

Then, by manually analysing titles and abstracts of all the documents, only those pertinent with the topic were considered for the deeper manual analysis in full text. This manual review phase was very onerous but nevertheless necessary, since the automatic filters of both databases, i.e. proximity operators and truncations for the query keywords, have proved unreliable in various sample tests, mainly as regards recall. Consequently, a drastic reduced the number of documents to be considered in the analysis resulted from the manual review.

The documents excluded from the analysis can be classified into four classes concerning the use of lasers: (i) as an alternative to pyrolysis; (ii) to perform operations (e.g. drying, cutting, surface finishing) on the reagents or on the pyrolysis products, without carrying out the same reaction; (iii) to measure the parameters of the pyrolysis reaction or the characteristics of the reactants and products; (iv) to realize some components of the pyrolysis reactor, e.g. electrodes, thermal vectors, masks/filters. The final pool counts 351 documents: 230 papers (articles) and 121 patents.

Based on the documents bibliographic information the documents were classified according to time distribution and their origin (i.e. academia vs industry). The papers in which all authors have academic affiliations, including research centres, and the patents in which at least an academic institution figures as applicant or co-applicant, were considered "academic". While the papers including at least one author with an industrial affiliation or co-affiliation and patents having only industries as applicants, were considered "industrial".

Figure 1 (left) shows the time distribution of the analysed papers and patents, considering the priority date for the latter, within the entire considered time interval. As can be seen, the distribution of the documents is growing, except for the last three years (2018-2020), since patents from first 18 months are not disclosed. Figure 1 (right) shows the distribution of the documents according to type (paper vs patent) and origin (academia vs industry).

\section{Results}

\section{Application fields}

In this section, we introduce the main application fields of the products of laser pyrolysis, considering only those explicitly declared by authors in the considered documents. All the applications fields have been classified according to a two-level hierarchical classification and distributed on a temporal axis to identify potential trends. The first level of the classification includes nine generic classes: (i) "Chemistry"; (ii) "Electronic" and (iii) "Electrochemical" products and components realization; (iv) "Medical" applications of laser pyrolysis or of its products; (v) "Environment" monitoring and preservation; (vi) "Precision manufacturing" operations; (vii) "Energy production" exploiting the reactions outputs; (viii) "Food production" monitoring and preservation; (ix) "Aerospace" products and components realization.

In the following paragraphs a brief description of each class is presented.

- The application of the laser pyrolysis to chemistry is linked to the production of catalysts for chemical reactions that have a higher efficacy and a lower manufacturing cost than alternatives produced with other technologies (e.g. Yeon et al., 2019). Furthermore, the use of laser pyrolysis in chemical industry is also confined to the pure production of materials to be successively processed (e.g. Malekzadeh et al., 2020) and for purposes related to the analysis of the properties and compositions of the materials, such as spectrometry (e.g. Prati et al., 2014).

- Laser pyrolysis in the electronics industry is used to produce mainly small parts or coatings of many products, such as: special electronic components where standard electrical conductivity or insulation capabilities are required together with miniaturization or flexibility or mechanical strength (e.g. Rahimi et al., 2016); solar cells, where the produced material have certain photo-
Fig. 1 (Left) Time distribution of papers and patents (priority date). (Right) Distribution between papers/patents, and source academia/industry
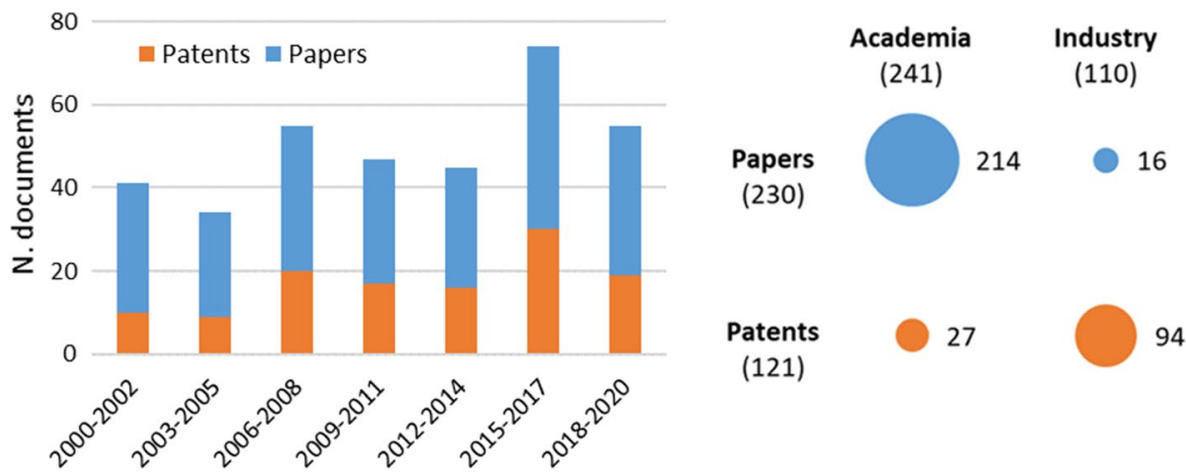
electric properties (e.g. Belchi et al., 2019); semiconductors, where laser pyrolysis is generally used both for the realization of silicon components and coatings (e.g. Jeong et al., 2017); superconductors, where the electrical properties are guaranteed by the increased control over the microstructure ensured by laser pyrolysis (e.g. Rijckaert et al., 2020); other electronic components used for the realization of displays, sensors and storage memories (e.g. Martins et al., 2019).

- Electrochemistry exploits laser pyrolysis to produce battery components, such as especially coatings for anodes and cathodes (e.g. Kim et al., 2019a, 2019b), supercapacitors (e.g. Bhattacharjya et al., 2018) and fuel cells (e.g. Yeon et al., 2019).

- Different medical applications exploit the products of laser pyrolysis. Powders are generally used in this field because thanks to their properties can act as a contrast for magnetic resonance (e.g. Popovici et al., 2007). Another option is to exploit them as ingredient for medications in order to favour a more localized action (e.g. Mejías et al., 2008). Finally, their chemical and biological properties are instead exploited in anticancer radiotherapy (e.g. Kabashin et al., 2019)

- Other fields of application of laser pyrolysis are: the protection and monitoring of the environment, e.g. through the production of catalyst nanopowders for air depollution (Barrault et al., 2009) or its direct application for the study of rocks as a measuring instrument (Al SandoukLincke et al., 2013), precision manufacturing, by replacing of other less performing technologies (Shin et al., 2020), energy production, exploiting the heat generated by the reaction of pyrolysis or producing gas that can be used as fuel (Masyuk et al., 2018), food production and conservation through the chemical action especially of nanopowders and coatings produced by laser pyrolysis (Wang et al., 2019) and aerospace.
Figure 2 summarizes the proposed classification in classes (in grey) and subclasses (in white) of the applications of the products of the laser pyrolysis.

Table 1 reports the number of documents referring to the various application fields.

Figure 3 depicts the comparison of the identified application fields between academia and industry.

Analysing the results shown in Table 1 and Fig. 3, some considerations can be drawn, in relation to the documents analysed and the proposed classification of the results. Each analysed document claims on average 1.07 different application fields, considering both classes and sub-classes, with a slight prevalence of industry contributions (1.13 applications) compared to those from the academia (1.04 applications). Overall, laser pyrolysis is mostly used in the field of chemistry and electronics, with about $75 \%$ of overall cases. Among the chemical applications, the production of catalysts (57\% of all chemical products), mainly nanopowder, and materials has been highlighted (35\% of all chemical products). In electronics, the production of special components, starting from nanopowders, alone counts for $49 \%$ of the cases. In electrochemical applications, the contribution from the production of batteries (69\% of the cases) is particularly noticeable, especially coatings. By comparing the distributions of the application fields, academia is strongly interested in chemical applications, with $49 \%$ of the total cases. Industry is instead more interested in electronics, although not in a less preponderant way, i.e. with a deviation of $4 \%$ respect to chemistry.

To provide an evidence about how the distribution of the application fields changed during time, in Fig. 4, the percentage distribution considering the aggregated data of all the considered documents in the last 20 years has been compared with that resulting by considering only the documents from the last 5 years. This comparison clearly showed that the main percentage variations can be encountered in

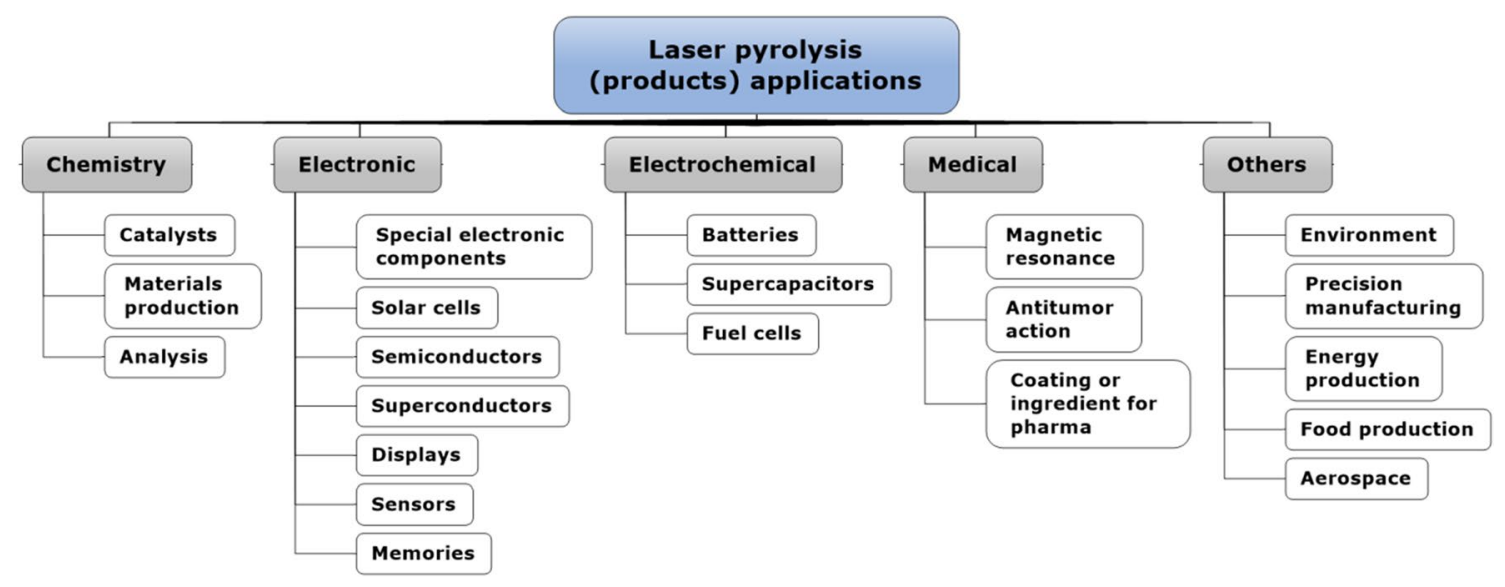

Fig. 2 Proposed classification of the identified applications fields of the products of the laser pyrolysis 
Table 1 Number of citations in papers/patents for each application field

\begin{tabular}{|c|c|c|c|}
\hline \multirow[t]{2}{*}{ Application fields } & \multicolumn{3}{|c|}{$\begin{array}{l}\text { Number of citations in papers/ } \\
\text { patents }\end{array}$} \\
\hline & Academia & Industry & Total \\
\hline \multicolumn{4}{|l|}{ Chemistry } \\
\hline Catalysts & 66 & 21 & 87 \\
\hline Materials production & 42 & 15 & 57 \\
\hline Analysis spectrometry & 15 & 6 & 21 \\
\hline Sub-total & 123 & 42 & 165 \\
\hline \multicolumn{4}{|l|}{ Electronic } \\
\hline Special electronic components & 34 & 23 & 57 \\
\hline Solar cells & 20 & 1 & 21 \\
\hline Semiconductors & 7 & 12 & 19 \\
\hline Superconductors & 1 & 4 & 5 \\
\hline Displays & 3 & 2 & 5 \\
\hline Sensors & 4 & 1 & 5 \\
\hline Memories & 0 & 4 & 4 \\
\hline Sub-total & 69 & 47 & 116 \\
\hline \multicolumn{4}{|l|}{ Electrochemical } \\
\hline Batteries & 12 & 7 & 19 \\
\hline Supercapacitors & 4 & 0 & 4 \\
\hline Fuel cells & 1 & 3 & 4 \\
\hline Sub-total & 17 & 10 & 27 \\
\hline Medical & 17 & 13 & 30 \\
\hline Environment & 8 & 4 & 12 \\
\hline Precision manufacturing & 7 & 3 & 10 \\
\hline Energy production & 4 & 4 & 8 \\
\hline Food production & 2 & 1 & 3 \\
\hline Aerospace & 3 & $\mathbf{0}$ & 3 \\
\hline Total & 250 & 124 & 374 \\
\hline
\end{tabular}

Bold values are used for the classes

electrochemical field $(+13 \%)$, other electronic fields $(-7 \%)$ and chemical analysis (-5\%).

Figure 5 shows the results of the analysis of the percentage distribution of publications relating to the different application fields of laser pyrolysis during time. In addition, in the two most common application fields, i.e. chemistry and electronic, the data were divided between academia and industry.

The analysis of the results shown in Fig. 5 provides an important clarification to the results emerged from Fig. 3. Although overall the most widespread applications of laser pyrolysis are those relating to chemistry and electronics, the percentage of the sum of the annual publications referring to them has been decreasing in the last twenty years. The aggregate percentage value of chemical and electronic applications passes from around $90 \%$ in the early 2000 s to around $60 \%$ in the last four years. Furthermore, this decrease is more pronounced in chemistry, which has lost a lot of interest especially in academia (-13\%), compared to electronics, which maintains a substantially stable interest in the academic field (+5\%). This decrease is due to the growing spread of laser pyrolysis applications, especially in electrochemistry (27 documents vs 1 ) and in other fields of applications. On the contrary, the values of medical applications seem rather fluctuating.

\section{Functions}

In this section, we introduce the main functions of laser pyrolysis, considering only those explicitly carried out by the same process as declared by authors in the considered documents. As consequence, the proposed analysis excludes all the secondary functions that can been carried out by the products of laser pyrolysis. The functions have been classified according to a hierarchical classification with multiple levels.

The first level of the classification includes six generic functions described in the following paragraphs.

- The laser pyrolysis can be used for generating solid materials, typically of micro or nanometric dimensions, exploiting the concentrated heat of the laser beam that crosses a flow of gaseous (typically) reagents, such as silane gas and germane gas, heating them rapidly and in an extremely focused way in the space. As a result, the chemical bonds of the molecules of the reagents, originating a supersaturated vapor from which the nucleation of particles takes place, whose nuclei grow by coagulation until solidification. Solid materials produced in this way are single particles, such as powders (e.g. Kim et al., 2019a, 2019b) and nanotubes (e.g. Bystrzejewski et al., 2009) or coatings (e.g. Tangermann-Gerk et al., 2016).

- The generation of fluid materials by laser pyrolysis can lead to the formation of gases such as: syngas (e.g. Patent No. WO2019159088, 2019), mainly comprising carbon monoxide, hydrogen and methane; pure hydrogen (e.g. Baymler et al., 2018), typically generated by processing the same materials used to obtain syngas but by raising the reaction temperature to obtain a greater molecular dissociation; and ethylene. Among the generated liquids we found oils and toluene above all.

- The laser pyrolysis can be used for special manufacturing operations on very small components and/or with high precision. This because the atmosphere inside to the reactor, necessary to carry out the pyrolysis reaction, drastically reduce the presence of contaminants that could negatively affect the results. Among the special manufacturing there are: additive manufacturing when particularly fine surface finishes are required (e.g. Vangelatos et al., 2020), marking and cutting with ultra-fine lines (e.g. Aminuzzaman et al., 2010) and drilling. 
Fig. 3 Distribution of the application fields for academia and industry

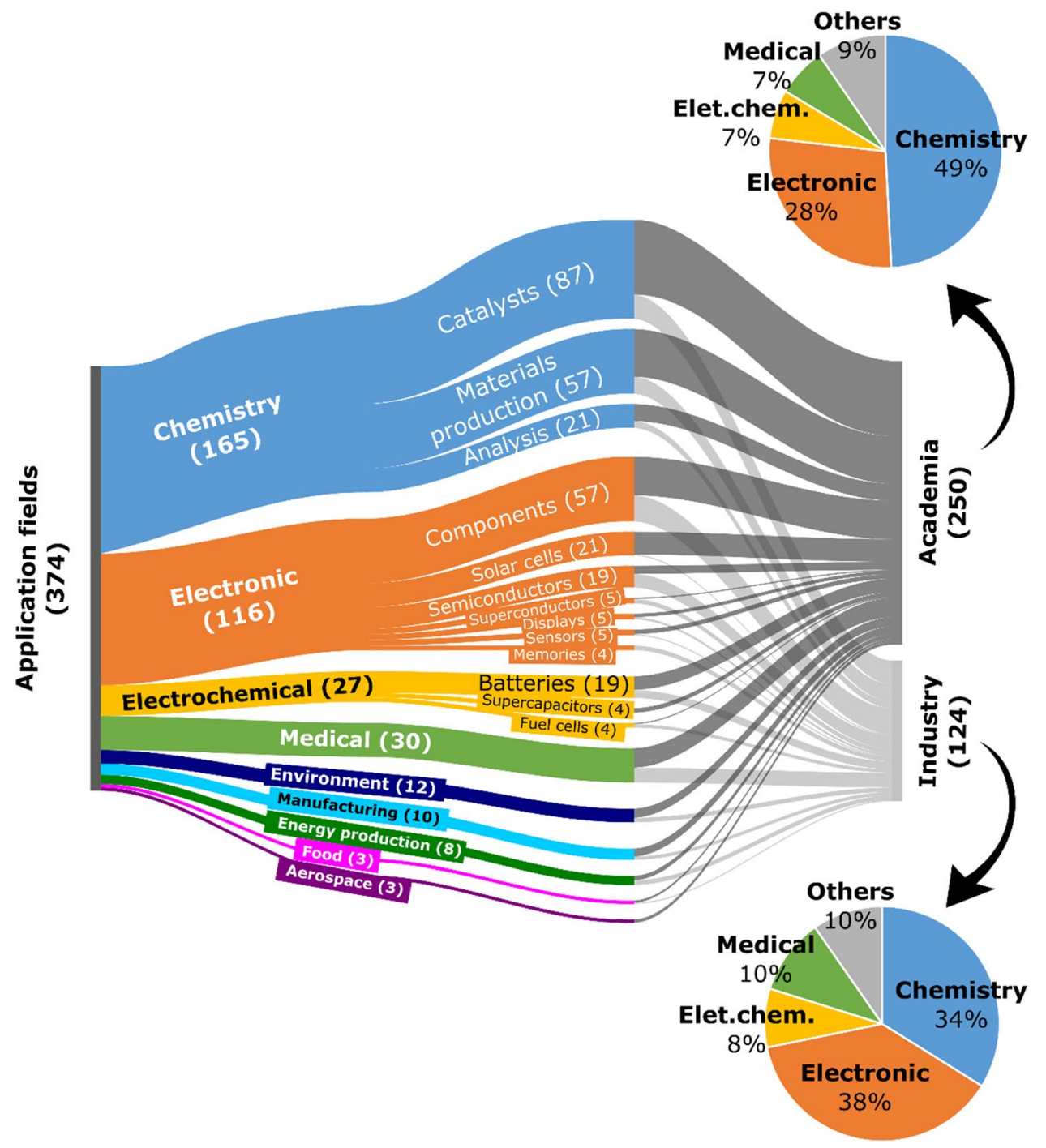

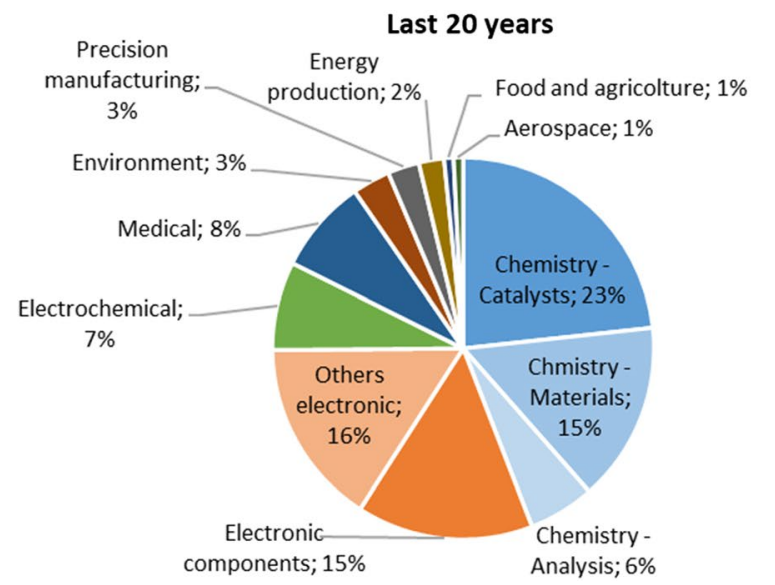

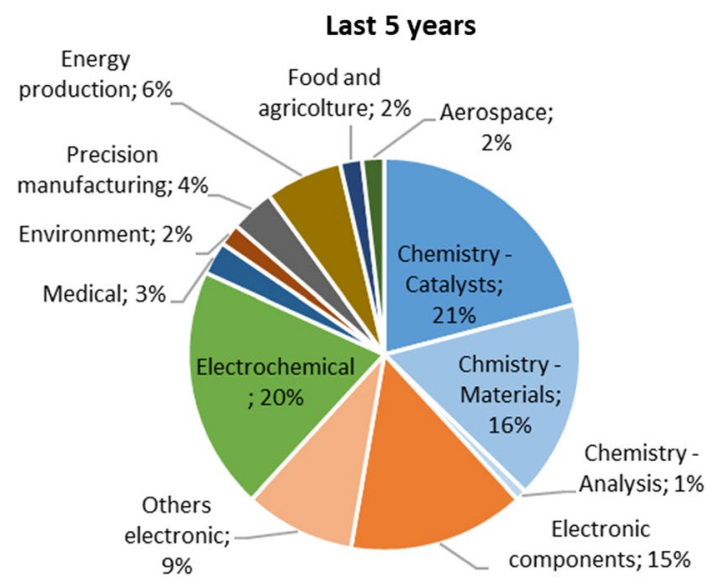

Fig. 4 Comparison of the percentage distribution of the application fields in all documents in the last 20 years and in the last 5 years 
Fig. 5 Percentage distribution of the application fields during time (where $\mathrm{A}=$ academia and $\mathrm{I}=$ industry)

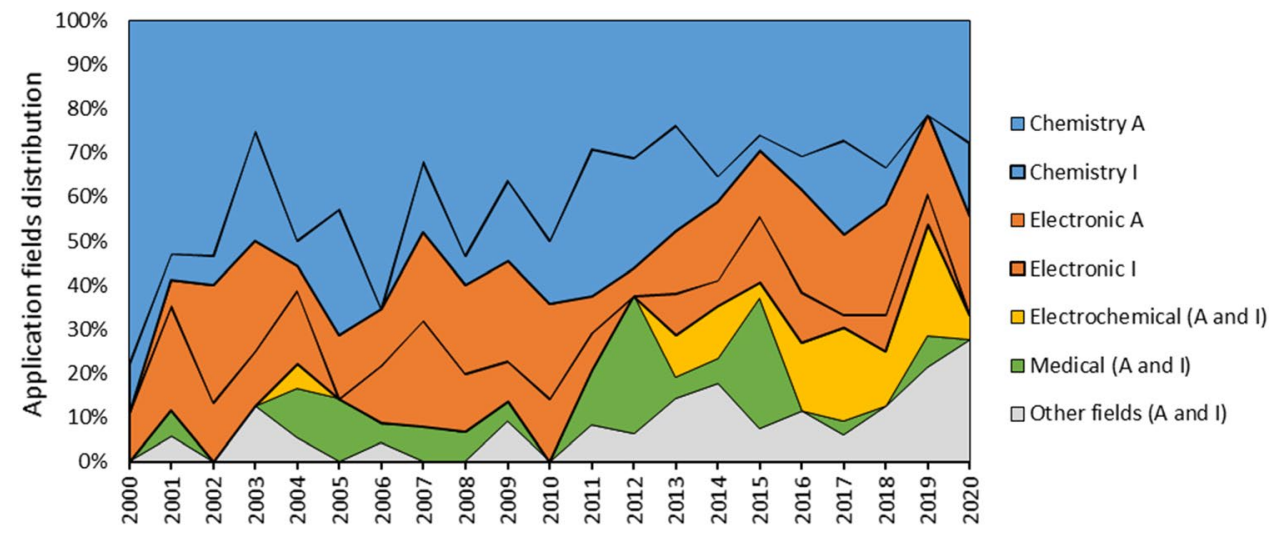

- The surface treatments (e.g. D'Amato et al., 2017) obtained with laser pyrolysis, without addition filler material, aim to obtain a certain porosity or to chemically stabilize a surface by removing a layer of material or an oxide and acting on the surface itself by plastic deformation in order to increase its hardness.

Finally, there is the use of laser pyrolysis to directly perform precision measurements such as spectroscopy (e.g. Marosfői et al., 2007) and eliminating wastes, providing them with the necessary amount of heat to perform pyrolysis (e.g. Patent No. WO2019159088, 2019).

Figure 6 summarizes the proposed classification of the functions of the laser pyrolysis, with the generic functions (in grey) and the subclasses (in white).

Table 2 reports the number of documents referring to the different described functions.
Figure 7 depicts the comparison of the identified functions between academia and industry.

Analysing the results reported in Table 2 and Fig. 7 some considerations can be drawn in relation to the analysed documents. On average, the industry works on slightly more functions than academia. Overall, laser pyrolysis is mostly used to generate materials, with over $97 \%$ of the total cases. Among them, solid materials constitute in turn the $91 \%$, where particle production is mentioned in more than twice as many documents as coatings production. Among the other considered functions only marginally, we highlight the uses of laser pyrolysis for special manufacturing ( $8 \%$ of the total), and for additives, and measuring (7\% of the total).

Comparing instead the distributions of the functions between academia and industry, we can note that in the first one, the generation of solids is greater than in the second one by as many as $14 \%$. Furthermore, academia is more interested than industry in the production of particles, claimed in

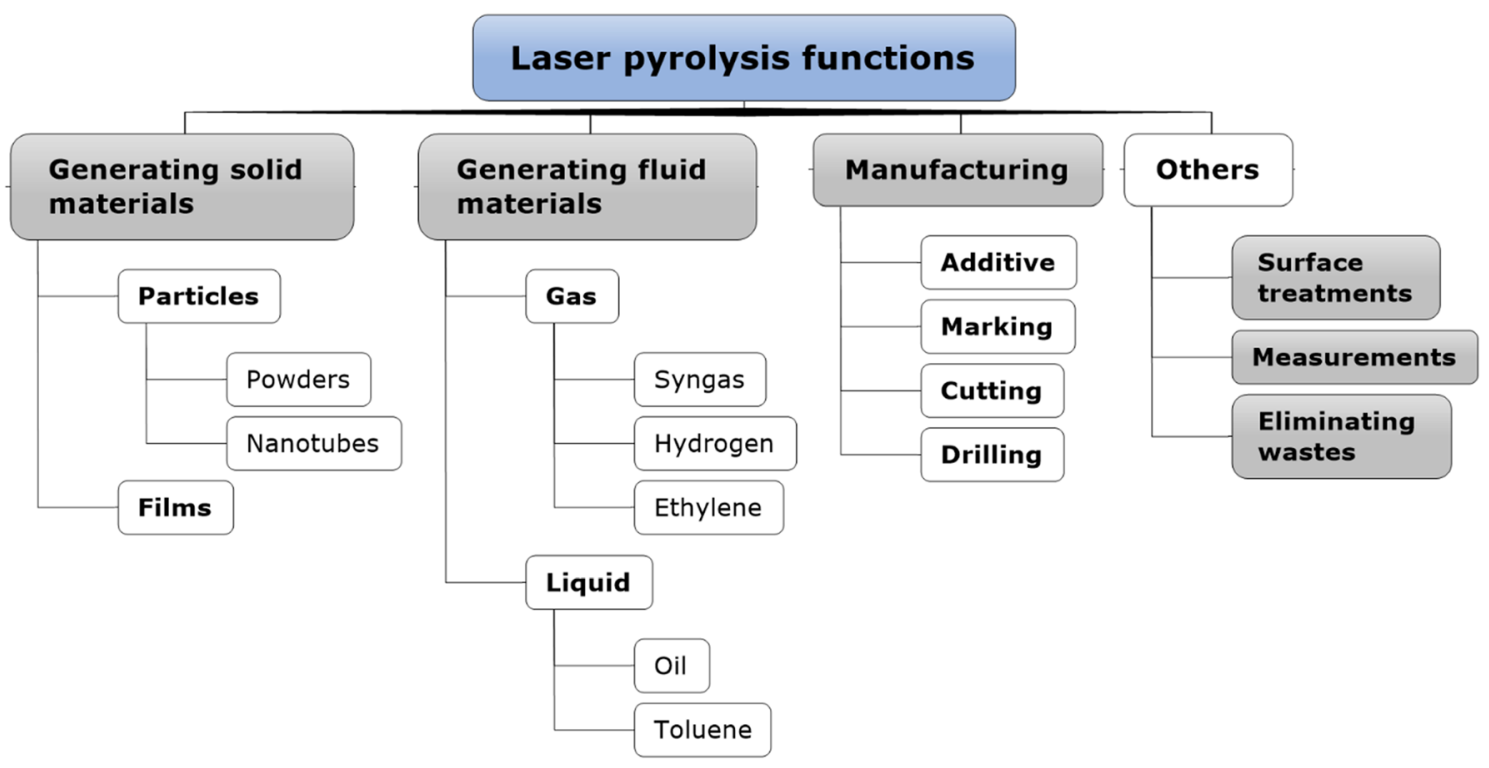

Fig. 6 Proposed classification of the identified functions of the laser pyrolysis 
Table 2 Number of citations in papers/patents for each function

\begin{tabular}{llll}
\hline Functions & \multicolumn{2}{l}{ Number of citations in papers/patents } \\
\cline { 2 - 4 } & Academia & Industry & Total \\
\hline Generating solid materials & & & \\
Particles & 149 & 63 & 212 \\
Film & 69 & 33 & 102 \\
Sub-total & $\mathbf{2 1 8}$ & $\mathbf{9 6}$ & $\mathbf{3 1 4}$ \\
Generating fluid materials & & & \\
Syngas & 6 & 4 & 10 \\
Oil & 3 & 5 & 8 \\
Hydrogen & 3 & 2 & 5 \\
Ethylene & 2 & 1 & 3 \\
Toluene & 1 & 1 & 2 \\
Sub-total & $\mathbf{1 5}$ & $\mathbf{1 3}$ & $\mathbf{2 8}$ \\
Manufacturing & & & \\
Additive & 8 & 6 & 14 \\
Marking & 3 & 4 & 7 \\
Cutting & 1 & 5 & 6 \\
Drilling & 3 & 3 & 6 \\
Sub-total & $\mathbf{1 5}$ & $\mathbf{1 8}$ & $\mathbf{3 3}$ \\
Surface treatments & $\mathbf{5}$ & $\mathbf{7}$ & $\mathbf{1 2}$ \\
Measurements & $\mathbf{2 2}$ & $\mathbf{1 0}$ & $\mathbf{3 2}$ \\
Eliminating wastes & $\mathbf{3}$ & $\mathbf{3}$ & $\mathbf{6 2 5}$ \\
Total & $\mathbf{2 7 8}$ & & \\
\hline Bold & & & \\
\hline
\end{tabular}

Bold values are used for the classes

almost $62 \%$ of the documents of the first one against $57 \%$ of the second one. While regarding coatings, the gap is reduced to only $2 \%$ in favour of the industry, always normalizing the number of functions by the number of documents from academia and industry. For other functions, we note the predilection of industry towards the generation of fluids $(+3 \%)$ and manufacturing $(+7 \%)$ compared to academia.

Finally, to provide an evidence about how the distribution of the functions changed during time, in Fig. 8, the percentage distribution considering the aggregated data of all the considered documents in the last 20 years has been compared with that resulting by considering only the documents from the last 5 years. This comparison showed that the generation of particles decreased by $8 \%$ compared to the average, while the generation of film increased by $5 \%$. While the percentage variations of the other functions are instead more contained.

\section{Generating solid materials}

Since the contributions related to the production of particles and coatings are by far the most widespread, we decided to analyse them better, classifying them according to their physical properties and the constituting materials, to provide new data for the discuss of this result. The identified properties of particles and coatings are: Chemical, exploiting their catalysing effect in various industrial environments as well as the affinity of polluted substances in order to clean the air or to produce water (e.g. Maskrot et al., 2006); Electrical, in terms of conductive, insulation or capacitive (e.g. Govender et al., 2014); Optical, being permeable in different ways to the light or emitting light when subjected to electric fields (e.g. Huisken et al., 2003); Magnetic, both in terms of actuation and catalytic (e.g. Kuncser et al., 2017); Mechanical, in terms of increased breaking strength (e.g. Horcher et al., 2020); Biological, ensuring biocompatibility within the human body for medical or food conservation and production purposes (e.g. Dumitrache et al., 2015); Thermal, mainly due to the high conductivity or insulation to heat transmission (e.g. Kruger et al., 2017). Furthermore, only for the coatings, other properties have also been identified, including resistance to surface corrosion (e.g. Horcher et al., 2020), hydrophobicity (e.g. Dumitrache et al., 2015) and superficial properties, i.e. roughness and hardness.

Figure 9 represents the distribution of the properties of particles and coatings in academia and industry, reporting the value of the number of documents referring to each property.

Analysing Fig. 9, we first notice two rather different distributions of the properties between the particles and the coatings. In the case of particles, chemical and electrical properties, more on an industrial level (corresponding to $59 \%$ of the total), and optical properties, especially in the academy (19\% of the total), are preferred. While all other properties are claimed in just over the $25 \%$ of the total cases. In the case of coatings, the attention to electrical properties, and to the increase in surface electrical conductivity, can be noted above all, both in academia (35\% of the total) and industry ( $40 \%$ of the total). In the other cases, the academia also shows a certain interest in surfaces and mechanical properties ( $19 \%$ of the total), while in industry, all the other properties are divided almost equally.

Figure 10 represents instead the distribution of the particles and coatings materials in academia and industry, reporting the value of the exact number of documents that refer to each chemical element. The identified elements can be found in form of oxides (generally) of alone as rare metals or polymers, although in many cases both particles and coatings consist of more elements (e.g. Silicon-Carbon Core-Shell Nanomaterials, Alper, 2017).

As can be seen from the analysis of Fig. 10, in the case of particles production, silicon is the most exploited material (31\% of the cases), generally in form of silicon oxide or rarely silicon carbide (e.g. Hofmeister et al., 1999), followed by iron (e.g. Dumitrache et al., 2005) and carbon (15\% of the cases), which in turn includes above all graphite, diamond and fullerene, although both iron and carbon have a diffusion mostly in academia. In the case of coatings, the diffusion 
Fig. 7 Distribution of the functions for academia and industry

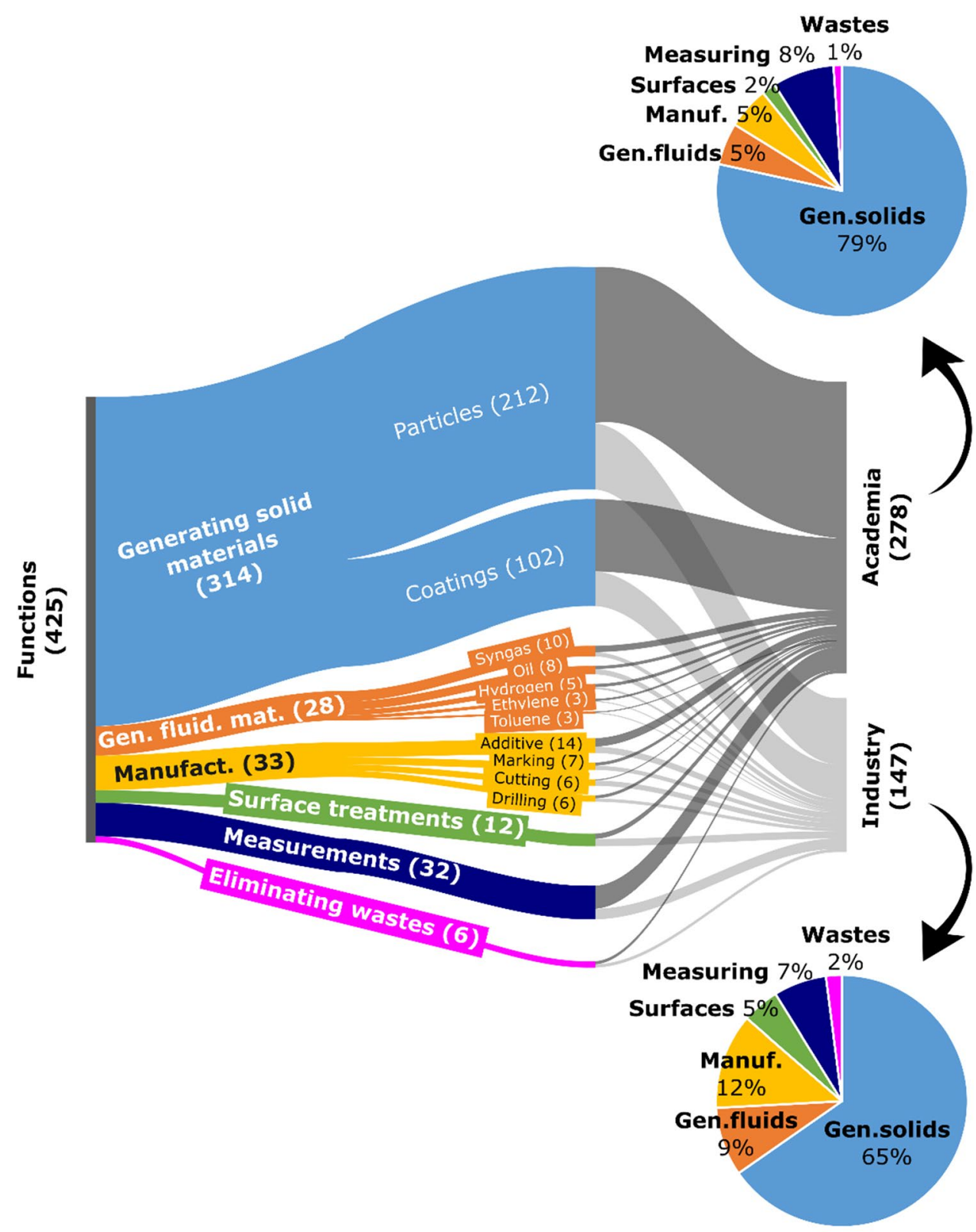

Fig. 8 Comparison of the percentage distribution of the functions in all documents in the last 20 years and in the last 5 years

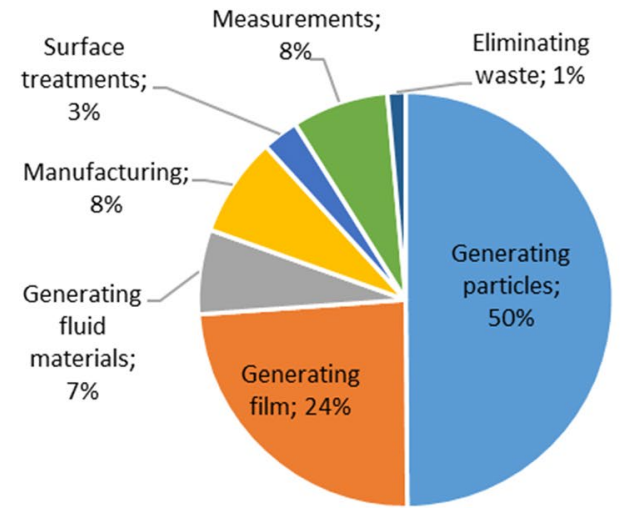


Fig. 9 Distributions of the properties of particles and coatings in academia and industry
Fig. 10 Distributions of the materials of particles and coatings in academia and industry
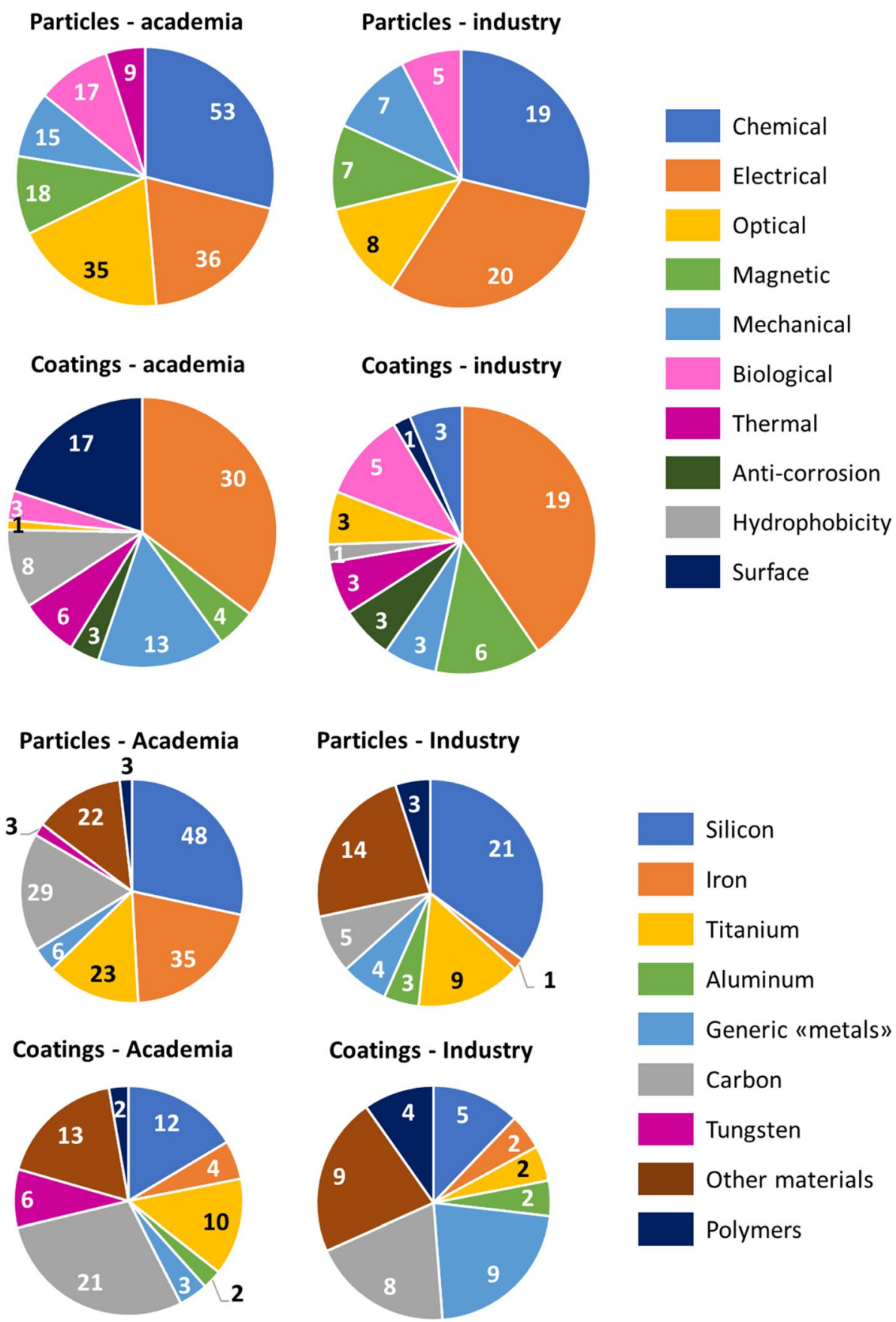

\section{Particles - Industry}

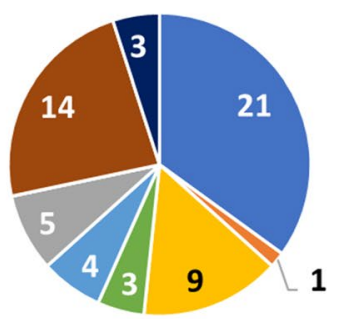

\section{Coatings - Industry}

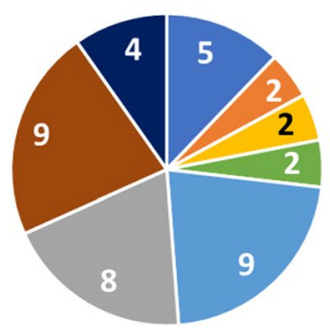

Silicon

Iron

Titanium

Aluminum

Generic «metals»

Carbon

Tungsten

Other materials

Polymers of carbon is noted above all, linked more to the academia ( $17 \%$ of the cases), and mainly due to the development of graphene (e.g. Qian et al., 2011) which accounts for most of the cases in this class, as emerged by analysing the documents. Other materials of both particles and coatings are: silver, quartz, tungsten, zirconium, vanadium, zinc, boron, barium, manganese, germanium, selenium, lithium, and tin. These materials are distributed in a homogeneous way both in particles and coatings, both in academy and in industry, without any significant preference. Finally, polymers are alternative to oxides and pure metals even if in very limited percentages both in particles and in coatings.

\section{Adopted laser technologies}

\section{Types of laser}

In this section, we introduce the adopted laser technologies for realizing the pyrolysis, considering only those source models and parameters explicitly declared by authors in the considered documents. Figure 11 shows 
Fig. 11 Distribution of the types of laser for realizing the pyrolysis in academia and industry

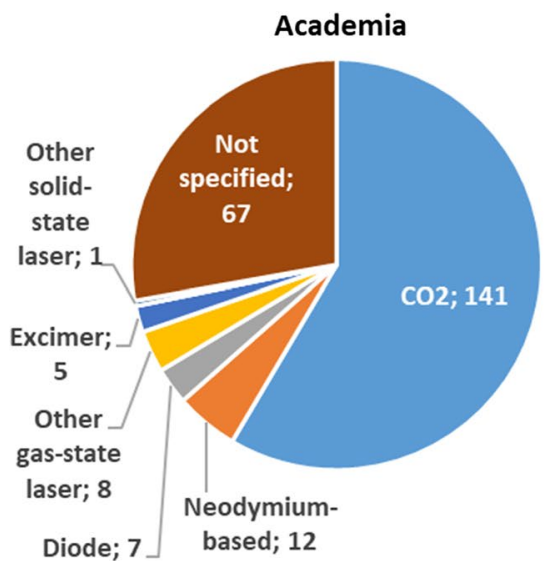

the distribution of the types of lasers used for pyrolysis, respectively claimed in the contributions of the academy and industry.

As can be seen from the analysis of Fig. 11, the $\mathrm{CO}_{2}$ laser is widely the most widespread, followed by the neodymiumbased, mainly Nd:YAG, and by diode lasers. In the case of the academy, the predominance of $\mathrm{CO}_{2}$ lasers is even more marked, in industry, solid-state laser and diodes are also used in a fair percentage of the total cases, while in more than a quarter of the total cases, the type of laser is not specified.

In general, the $\mathrm{CO}_{2}$ lasers, which have an emission wavelength around 9-10 nm, are ones of the most widespread and well-known in the world, and ones of the first power lasers. Like other gas-state lasers, their equipment is quite voluminous, consisting of a tube for the cavity with a length at least equal to $50 \mathrm{~cm}$, or more commonly to one meter. Finally, the powers are significative, and the selling price are decent.

Solid state lasers, and in particular Nd families, which emit a wavelength around $1 \mathrm{um}$, are the most accurate. Their powers are equal or higher than $\mathrm{CO}_{2}$ lasers, even if with a higher cost. These lasers are more easily controlled, even directly via PC, and have spectral purity and quality of the optical beam far superior to $\mathrm{CO}_{2}$, but these characteristics are not always worth the price differences, although decreasing in the last period.

Diode lasers have emission wavelength of $600-800 \mathrm{~nm}$, powers comparable to solid-state lasers, ease integration and management and a small size. Usually, their cost is lower than solid-state lasers, while the wall plug efficiency, i.e. the ratio between the optical power emitted and the electrical power necessary for their operation, is always greater than $50 \%$. On the other hand, their optical beam is limited and much worse than solid-state lasers. For this reason, their use is generally excluded when high precision is required. High temperature stability can also be controlled, although solid-state laser is generally more reliable for this purpose.

Figure 12 shows the distribution of the main types of lasers used for pyrolysis according to the most diffused functions and application fields.

Analysing Fig. 12, the overall distribution of laser types is substantially reflected also within the single functions and application fields. The cases that differ most from the general distribution are, in the case of functions, the generation of powders and fluids, where there is a more marked
Fig. 12 Comparison between most diffused types of laser sources, functions, and application fields in laser pyrolysis
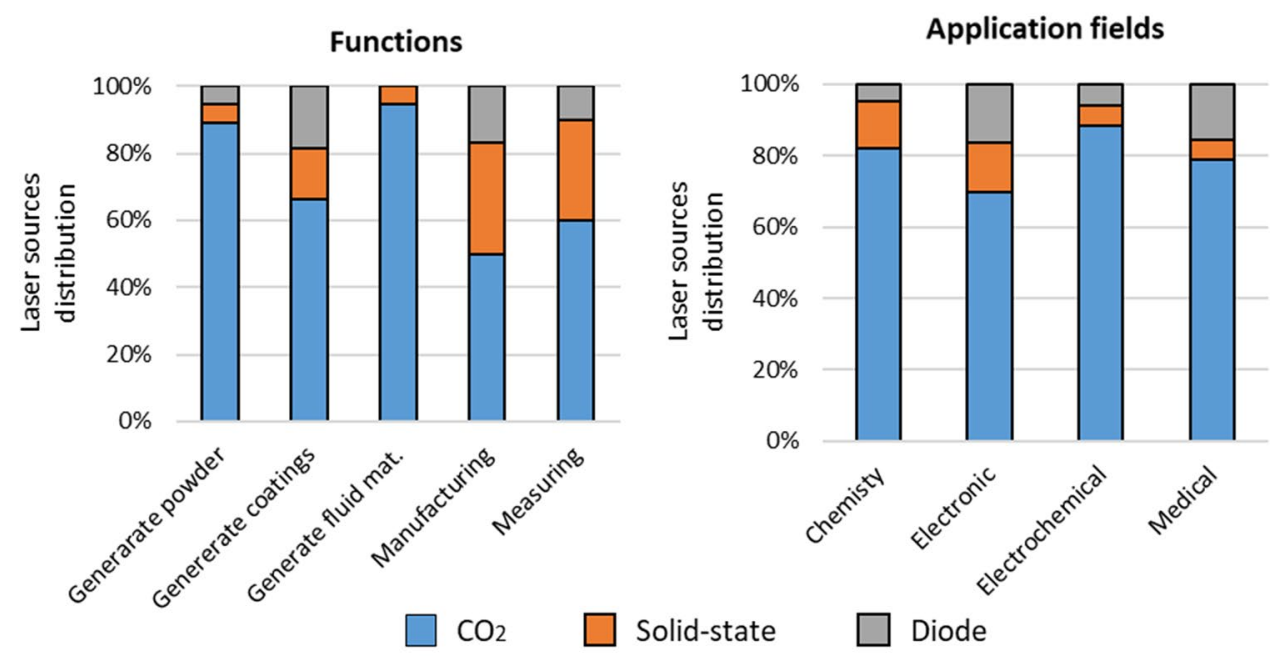
use of $\mathrm{CO}_{2}$ lasers, manufacturing and measuring, where instead $\mathrm{CO}_{2}$ lasers are only just over half of the total cases, and instead there is a greater use of the neodymium-based laser. In the case of application fields, on the other hand, the distributions between the different categories are more like each other and the $\mathrm{CO}_{2}$ lasers is the more considered.

\section{Laser performances}

In this section, the performances of the types of used lasers are analysed according to their powers and fluences for realising the pyrolysis, only in documents where such values were explicitly stated. Table 3 reports the results, by specifying the source, the types of laser and the achieved functions. Its compilation required some attention since we had to discriminate, where possible and especially in patents, the values indicated as "preferable" from those that are simply claimed. In fact, in patents there is a tendency to declare a range of values for a given sensitive parameter rather than its precise value, to obtain greater legal protection, and eventually to suggest a narrower range or a value, contained in the first range, to ensure the better performances.

Table 3 Identified values of power and fluence of the used types of lasers for realizing the main functions (where * indicates values claimed but not described as preferable)

\begin{tabular}{|c|c|c|c|c|}
\hline Lasers & Functions & Document & Power (W) & Fluence $\left(\mathrm{W} / \mathrm{cm}^{2}\right)$ \\
\hline \multirow[t]{26}{*}{$\mathrm{CO}_{2}$} & \multirow[t]{22}{*}{ Generating particles } & Laguna-Marco et al. (2014) & 82 & 652 \\
\hline & & Dumitrache et al. (2005) & $55-75$ & $1100-1500$ \\
\hline & & Govender et al. (2014) & n.a & 51.2 \\
\hline & & Réau et al. (2012) & $1000-5000$ & $150-2050$ \\
\hline & & Gavrila-Florescu et al. (2017) & 130 & 1680 \\
\hline & & Kim et al. (2015) & 57 & n.a \\
\hline & & Jäger et al. (2009) & n.a & $850-6400$ \\
\hline & & Galvez et al. (2002) & $250-800$ & n.a \\
\hline & & Leconte et al. (2007) & 2400 & n.a \\
\hline & & RO131729 & 100 & n.a \\
\hline & & DE10296273 & n.a & $7-108$ \\
\hline & & US10023813 & 1200 & $1200(1000 *-10,000 *)$ \\
\hline & & CN108465814 & $50-400$ & n.a \\
\hline & & CN107043259 & $9\left(5 *-55^{*}\right)$ & n.a \\
\hline & & WO2017/039477 & n.a & 10 \\
\hline & & WO2008/118865 & $104(30 *-300 *)$ & n.a \\
\hline & & WO2006/051233 & 5000 & 750 (up to $25,000^{*}$ ) \\
\hline & & US7601321 & 58.5 & 2000 \\
\hline & & US10199177 & 640 & n.a \\
\hline & & FR2984867 & 5000 (up to) & n.a \\
\hline & & KR101841558 & $200-700$ & n.a \\
\hline & & EP3395437 & 500 & n.a \\
\hline & \multirow[t]{2}{*}{ Generating coatings } & Tiliakos et al. (2020) & n.a & 0.26 \\
\hline & & CN111403691 & $40\left(5^{*}-500^{*}\right)$ & n.a \\
\hline & Generating fluid materials & BR102013031976 & $60(20 *-100 *)$ & n.a \\
\hline & Measurements & RU145336 & n.a & $0.005-1$ \\
\hline \multirow[t]{5}{*}{ Solid-state } & Generating particles & Wilden and Fischer (2007) & 900 & $\mathrm{n} . \mathrm{a}$ \\
\hline & \multirow[t]{4}{*}{ Generating coatings } & CN108281490 & 1000 & $1-500$ \\
\hline & & JP5066686 & n.a & $0.001-0.1$ \\
\hline & & RO132432 & $4.8-6$ & n.a \\
\hline & & JP4799459 & n.a & $0.015-0.4$ \\
\hline \multirow[t]{6}{*}{ Diode } & \multirow[t]{2}{*}{ Generating particles } & Lin et al. (2014) & 106 & n.a \\
\hline & & US20100308286 & 600 & 2000 \\
\hline & \multirow[t]{4}{*}{ Generating coatings } & Qiao et al. (2018) & $350-800$ & n.a \\
\hline & & CN109402615 & 300 & n.a \\
\hline & & JP2002274950 & n.a & $0.03-0.1$ \\
\hline & & CN105821400 & $500(300 *-800 *)$ & n.a \\
\hline
\end{tabular}




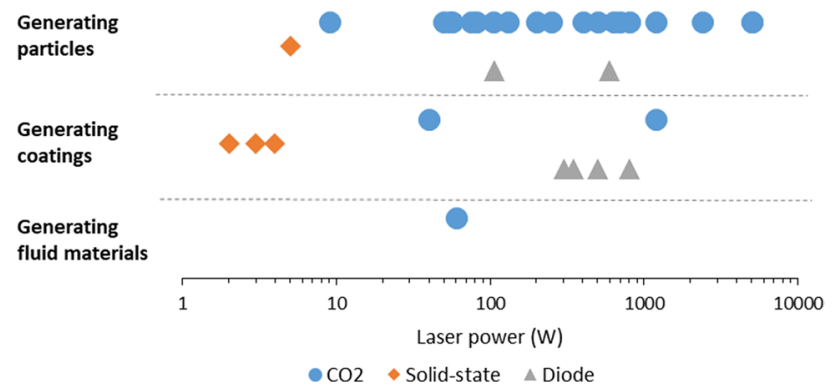

Fig. 13 Comparisons between types of laser, power, and main functions from the analysed documents

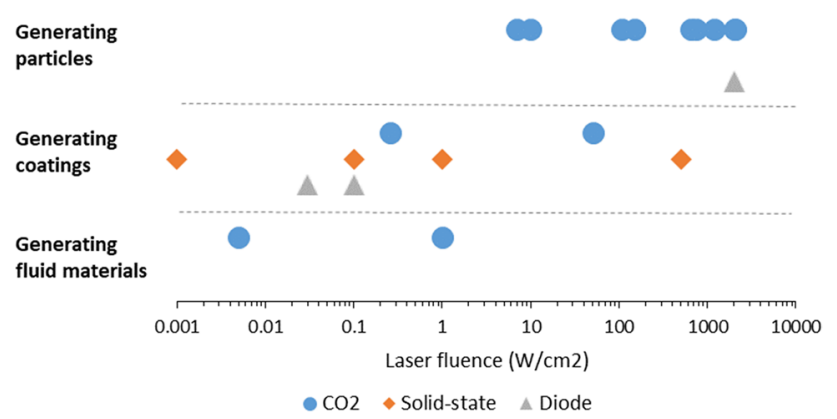

Fig. 14 Comparisons between types of laser, fluence, and main functions from the analysed documents

Figure 13 graphically represents the results about the powers of the laser (see Table 3), by considering only those explicitly declared preferable values.

Figure 14 graphically represents the results about the fluences of the laser (see Table 3), by considering only those explicitly declared preferable values.

Analysing the results shown in Figs. 13 and Fig. 14 emerges that for $\mathrm{CO}_{2}$ lasers, the ranges of powers and fluence are much wider than in other types of lasers. While comparing the performances of the lasers for the different functions, generating particles emerged to be the one requiring the highest power and fluence and widest ranges of power, although, this is more evident for $\mathrm{CO}_{2}$ lasers.

\section{Discussion of the results}

The obtained results communicate that laser pyrolysis technology, for some years, has been having an academic and industrial interest due to its versatility towards several different uses and applications. Although our study does not compare laser pyrolysis with competing technologies, we nevertheless believe that the detailed discussion of the obtained results, proposed in this section, may highlight some of its more unique advantages. Within this aim, in the following paragraphs, the results are discussed, by comparing functions, application fields and types of laser.
Table 4 summarizes the main advantages that have been identified for the different applications of laser pyrolysis in relation to any most suitable types of lasers.

\section{Generating solid materials (particles and coatings)}

This study clearly demonstrated that, apart from rare exceptions, laser pyrolysis is a technology mainly dedicated to the production of solids (particles and coatings), mostly nanometric in size, starting from gaseous precursors. In this field, the process has been refined over the last twenty years, significantly improving the quality of the generated solid products and allowing them to be exploited in an increasing number of different application fields (see Fig. 4). This is mainly due to the improvement of the exploited technologies and the optimization of the process parameters that have made it possible to generate particles and coatings with many different properties and materials (see Fig. 9 and Fig. 10).

The analysis of the technologies proposed in "Adopted laser technologies" section. is a possible starting point for discussing these aspects. From it, $\mathrm{CO}_{2}$ lasers were found to be the most suitable for generating particles (see Fig. 12). A possible justification for this aspect may be due to their wide range of regulation of power and fluence during the particles production (see Fig. 13 and Fig. 14). This fact, according to Sublemontier et al. (2009), is the main advantage of this technology that allows its better adaption to the different geometric, mechanical, and magnetic properties of the nanopowders, as well as to obtain many different materials (Veintemillas-Verdaguer et al., 2003). Similar considerations can be made for the coating production, although in relation to a smaller number of results and applications fields and with a more homogeneous distribution among the types of lasers. While more detailed considerations can be made in relation to the different application fields, while also investigating the specific technological aspects.

In chemical applications, for the realization of particles and coatings with catalyst functions, where the control of the microstructural aggregation and chemical properties is required, pulsed lasers are preferable being able to generate a series of continuous heating and cooling favouring these properties (Ishikawa et al., 2016). When the goal is to maximize the production of nanoparticles and nanocoatings, continuous $\mathrm{CO}_{2}$ lasers are particularly suitable, allowing to balance the exposure though continuous power flow (Jamkhande et al., 2019). Instead, only through the precise spatial control of the energy supplied to the gaseous precursor, which the $\mathrm{CO}_{2}$ laser pyrolysis can ensure, a deposition of bimetallic coatings starting from the same precursor can be obtained. In this way, according to Martinez et al. (2018), the catalytic properties of the coating are improved.

In electronic applications, for the production of semiconductors, the Nd:YAG laser allows to obtain nanopowders of silicon oxides averagely having a greater purity, and therefore 
Table 4 Main advantages of laser pyrolysis in relation to the application fields and the eventual most suitable laser technologies

\begin{tabular}{|c|c|c|}
\hline Application fields & Laser pyrolysis advantages & Preferred types of laser \\
\hline \multirow[t]{5}{*}{ Chemistry } & $\begin{array}{l}\text { Producing catalytic particles and coatings with microstructural and chemical properties optimiza- } \\
\text { tion }\end{array}$ & Pulsed $\mathrm{CO}_{2}$ \\
\hline & Maximize the production of nanostructures & Continuous $\mathrm{CO}_{2}$ \\
\hline & Realizing bimetallic coatings to increase the catalytic properties & $\mathrm{CO}_{2}$ \\
\hline & Increasing the mass production of ethylene & IR \\
\hline & Reducing the energy consumption during the production of light olefins & $\mathrm{CO}_{2}$ \\
\hline \multirow[t]{4}{*}{ Electronics } & $\begin{array}{l}\text { Increasing the electrical and magnetic properties of silicon oxides nanopowders used for semicon- } \\
\text { ductors }\end{array}$ & Nd:YAG \\
\hline & Increasing the control over the thickness of coatings/deposition layers in integrated circuits & Nd:YAG \\
\hline & Improving the insulating properties of ceramic coatings & Nd:YAG \\
\hline & Improving the photoelectric properties of particles and coatings used for solar cells & $\mathrm{CO}_{2}$ \\
\hline Electrochemistry & $\begin{array}{l}\text { Increasing the life of the carbon nanoparticles that make up the membranes of fuel cells, and conse- } \\
\text { quently their durations }\end{array}$ & $\mathrm{CO}_{2}$ \\
\hline \multirow[t]{3}{*}{ Biomedical } & Producing drug coatings with greater and more controlled biodegradability & \\
\hline & Making nanopowders to treat cancer in a more localized way & Pulsed $\mathrm{CO}_{2}$ \\
\hline & Optimizing the surface finish of prostheses to reduce the time for the welding with the bone & \\
\hline \multirow[t]{2}{*}{ Waste treatment } & Improving the properties of the syngas produced by the waste pyrolysis & Pulsed diode \\
\hline & Improving the efficiency and reducing the process times & \\
\hline
\end{tabular}

better electrical and magnetic properties, than those prepared with other technologies (Liu et al., 2017). As for the realization of integrated circuits, where it is essential to guarantee a very precise control of the thickness of the deposited coating and at the same time to realize net discontinuities of the thicknesses, even in very close areas, the laser pyrolysis based on Nd:YAG preferable option, allowing to adjust the depth of penetration of the focus point very precisely (Shamardin et al., 2019). To create electrical and thermal insulators in the form of coatings, typically consisting of ceramic materials, laser pyrolysis (with $\mathrm{Nd}$ :YAG) has proved to be one of the most reliable options. In fact, its pulsation can be optimized to increase the microstructural quality and reducing bubbles (Tangermann-Gerk et al., 2016). Furthermore, the possibility of creating, especially with $\mathrm{CO}_{2}$ lasers, powders and coatings with strong photoelectric properties is the basis of the recent use of laser pyrolysis in the production of solar cells (Belchi et al., 2019).

In electrochemistry, the use of $\mathrm{CO}_{2}$ laser has instead allowed to generate various types of carbon nanoparticles used for the proton exchange membranes of fuel cells, which have a superior durability and electrical conductivity, and which therefore also allow to improve the durability of the same cells (Yeon et al., 2018).

In medical applications, the fine control on the microstructural properties of powders and coatings, which can be ensured by laser pyrolysis, can guarantee their natural and controlled degradation within the human body, thus making them particularly useful for realizing capsules for drug delivery. (Kabashin et al., 2019). The ability of laser pyrolysis to create increasingly smaller nanopowders, using $\mathrm{CO}_{2}$ pulsed lasers, synthesizing biocompatible materials at the same time, is the basis of their application for the treatment of cancer. This because in this field, a focused action on diseased cells, ensured by the laser, is crucial to not damage the healthy surrounding tissues (Gavrila-Florescu et al., 2017). While the control on the surface finish allows to optimize the roughness and porosity of implantable prostheses, e.g. bone scaffolds and joint replacements, to promote better surface interaction and then welding with the bone, by reducing the patient recovery times (Patent No. WO2015121369A1, 2015).

\section{Generating fluid materials}

Although laser pyrolysis has been exploited only marginally for producing fluids, this technology can guarantee two main advantages if compared to concurrent technologies, according to what we learned from the considered documents. During the production of ethylene, which is widely used in chemical industry to produce various rubbers, and synthetics plastics, IR laser can increase the production rate up to $25 \%$ compared to the conventional steam cracking method (Stadnichenko et al., 2014). While during the production of light olefins starting from hydrocarbons, $\mathrm{CO}_{2}$ laser induced pyrolysis can instead save energy compared to other pyrolysis methods used for this purpose, which reactors also have high wall temperature and producing large amounts of undesired carbonaceous side-products (Masyuk et al., 2018).

\section{Eliminating wastes}

The development of laser pyrolysis in the field of waste elimination could open important growth prospects for this technology, 
which can compete with other pyrolysis technologies. The advantages of laser pyrolysis compared to these latter, such as fixed bed, fluidized bed and hot sands, concern both the simplification of the systems, with the elimination of voluminous heating and recirculation systems of the thermal carrier, the ensured portability, and the increased heating efficiency, since mechanical energy-intensive heating mediums can be substituted by heat source directed into the raw material. Laser pyrolysis could also be better than the most modern and radiationbased pyrolysis technologies such as microwave and plasma, both by raising the reaction temperature compared to the first one and increasing the efficiency and heating rate compared to the latter, being able to focus more the transmission of heat on the raw material (i.e. waste). The experiments of Zaitsev et al. (2018) on laser pyrolysis, with pulsed diode laser, and waste gasification showed reduced processing times and good properties of the generated syngas. This latter can be considered a valid fuel because of its calorific value and the high percentage of hydrogen. Finally, Patent No. WO2019159088 (2019) proposes a particularly significant system for this application field, proposing laser pyrolysis for eliminating different types of wastes, including rubber, bitumen and tires, and the production of syngas. In this invention, the waste transits on a conveyor belt and is hit by a beam of lasers arranged in parallel that point from above. The syngas is sucked from the top of the reactor, while the ashes remain on the conveyor belt.

\section{Other functions}

Laser pyrolysis has been proposed in various sectors of manufacturing and surface cleaning, allowing some advantages, albeit with few contributions relating mostly to niche applications and which remain confined to academic research. As part of the measurement, laser pyrolysis has been an option for chromatography since the late sixties. Compared to its first applications limited to the characterization of very small portions of coal and polymers, the most recent proposals enlarged the number of analysed materials and compared to traditional gas chromatography and the chromatography based on pyrolysis (without laser), ensure the possibility to perform non-destructive tests by significantly reducing the execution times. Despite these advantages, the publication trend on the subject has been declining over the past 15 years. Among the documents identified in this context, Patent No. US10054577B2 (2015) proposes a spectroscopy method for determining chemical characteristics of geological samples, rocks and which can also be extended to stone materials for construction and concrete.

\section{Conclusions}

In this paper, a survey about the last twenty years of more than 350 publications about laser pyrolysis has been proposed to identify and compare main functions, application fields and technological aspects. The main novelty concerns the use of both papers and patents, to provide comparative perspective on how academia and industry are moving on the subject. Each document has been manually analysed and the main outputs of this work were accurately presented and discussed. In addition, the conjunct analysis of functions, application fields and technological aspects allowed to highlight some interesting intersections particularly interesting for professionals dealing with technology transfer.

The analysis of the application fields showed the predominant use of laser pyrolysis in chemistry and electronics, where academia is more oriented towards the first field, while industry in the second. In chemistry the focus is mainly on the production of catalysts and materials, while in electronics on micro-components and solar cells. While the study of the time trend showed that these fields have been declining in the last twenty years and new opportunities are being investigated, such as the production of batteries, components for the medical sector and for environmental protection.

For what concerns the functions carried out with laser pyrolysis, academia resulted more interested in the production of nanoparticles, while industry in coatings characterized by a greater variety of physical and chemical properties. Among them, chemical, electronic (e.g. super or semi conduction), optical (e.g. photoconduction) and magnetic properties are the most searched both by academia and industry.

The analysis of the types of lasers highlighted the predominant use of $\mathrm{CO}_{2}$ lasers, followed at a distance by neodymium-based and diode ones. The analysis of the laser power and fluence ranges also showed the versatility of the $\mathrm{CO}_{2}$ laser compared to others, although this data should be read mainly in function of the large number of $\mathrm{CO}_{2}$ laser applications identified among the analysed documents. According to the analysis of the power and fluence of lasers, patents tend to be less reliable, providing ranges and values that are sometimes even imaginative, without considering the real industrial realization.

Finally, the intersection between the three aspects of the analysis allowed to highlight some common advantages of laser pyrolysis, and to hypothesize, by virtue of these characteristics, possible future expansions. Among them there are the production of bi-material nanoparticles and coatings with different properties, especially useful in medicine for the cure of cancer, and the waste (tyres) processing, where laser pyrolysis can be more efficient than traditional pyrolysis, by reducing the process energy consumption, increasing the cycle time, and obtaining syngas.

The planned future developments of this study concern an expansion towards the technological aspects, in terms of the types of lasers and systems, as well as on their current state of development, which can be used to obtain the different functions in the different application fields. In addition, the most innovative and strategic fields of application, even 
purely theoretic, which have been highlighted in this study, could be monitored, updating this analysis periodically with new documents, to intercept new opportunities as soon as their development could take off.

\section{Appendix}

See Table 5.

Table 5 Classification of all the considered sources divided between papers and patents

\begin{tabular}{|c|c|c|c|c|}
\hline Sources & $\begin{array}{l}\text { Academia (A) } \\
\text { or Industry (I) }\end{array}$ & Fields & Functions & Lasers \\
\hline \multicolumn{5}{|l|}{ Papers } \\
\hline $\begin{array}{l}\text { Abd Elrahman and Mansour } \\
\text { (2019) }\end{array}$ & A & Medical & Particles & n.a \\
\hline Ahlhelm et al. (2013) & A & Precision manufacturing & Additive & n.a \\
\hline $\begin{array}{l}\text { Al Sandouk-Lincke et al. } \\
\text { (2013) }\end{array}$ & A & Environment & Measurements, Drilling & n.a \\
\hline Alexandrescu et al. (2010a) & A & Materials production & Particles & $\mathrm{CO}_{2}$ \\
\hline Alexandrescu et al. (2010b) & A & Electronic components & Particles & $\mathrm{CO}_{2}$ \\
\hline Alexandrescu et al. (2009) & A & Electronic components & Particles & $\mathrm{CO}_{2}$ \\
\hline Alexandrescu et al. (2004) & A & Catalysts & Particles & $\mathrm{CO}_{2}$ \\
\hline Allen and Russell (2004) & A & Analysis & Measurements & $\mathrm{CO}_{2}$ \\
\hline Allen and Russell (2002) & A & Catalysts & Particles & $\mathrm{CO}_{2}$ \\
\hline Aminuzzaman et al. (2010) & A & Materials production & Particles, Marking & Ion \\
\hline Aminuzzaman et al. (2009) & A & Electronic components & Film & $\mathrm{CO}_{2}$ \\
\hline Aminuzzaman et al. (2008) & A & Solar cells & Film & $\mathrm{CO}_{2}$ \\
\hline Bachmatiuk et al. (2009) & A & Electronic components & Particles & $\mathrm{CO}_{2}$ \\
\hline Badoi et al. (2016) & A & Materials production & Particles & n.a \\
\hline Bădoi et al. (2015) & A & Medical & Particles & n.a \\
\hline Bahgat (2006) & A & Materials production & Particles & n.a \\
\hline Baia et al. (2011) & A & Catalysts & Particles & $\mathrm{CO}_{2}$ \\
\hline Balas et al. (2018) & A & Electronic components & Film & $\mathrm{CO}_{2}$ \\
\hline Barrault et al. (2009) & $\mathrm{A}$ & Environment & Particles & $\mathrm{CO}_{2}$ \\
\hline Baskakov et al. (2018) & A & Catalysts & Particles & Excimer \\
\hline Belchi et al. (2019) & $\mathrm{A}$ & Solar cells & Particles, Film & n.a \\
\hline Bhattacharjya et al. (2018) & A & Supercapacitors & Film & $\mathrm{CO}_{2}$ \\
\hline Bodzay et al. (2009) & A & Analysis & Measurements & $\mathrm{CO}_{2}$ \\
\hline Bomatí-Miguel et al. (2008) & A & Catalysts & Particles & $\mathrm{CO}_{2}$ \\
\hline Bomatí-Miguel et al. (2006) & A & Materials production & Particles & $\mathrm{CO}_{2}$ \\
\hline Bomatí-Miguel et al. (2005) & A & Medical & Particles & $\mathrm{CO}_{2}$ \\
\hline Botti et al. (2001) & A & Catalysts & Particles & $\mathrm{CO}_{2}$ \\
\hline Bouclé et al. (2005) & A & Catalysts & Particles & Ion, He_Ne \\
\hline Bouhadoun et al. (2017) & A & Catalysts & Particles & $\mathrm{CO}_{2}$ \\
\hline Bouhadoun et al. (2015) & A & Catalysts & Particles & $\mathrm{CO}_{2}$ \\
\hline Bourrioux et al. (2017) & $\mathrm{A}$ & Batteries & Particles & $\mathrm{CO}_{2}$ \\
\hline Bystrzejewski et al. (2009) & A & Materials production & Particles & $\mathrm{CO}_{2}$ \\
\hline Bystrzejewski et al. (2008) & A & Catalysts & Particles & $\mathrm{CO}_{2}$ \\
\hline Chen et al. (2020) & A & Catalysts & Particles & $\mathrm{CO}_{2}$, excimer \\
\hline Chen et al. (2013) & I & Electronic components & Film & Diode \\
\hline Chen and Mao (2006) & A & Semiconductors & Film & $\mathrm{CO}_{2}$ \\
\hline Chizhik et al. (2009) & A & Solar cells & Particles & $\mathrm{CO}_{2}$ \\
\hline Choi et al. (2017) & A & Catalysts & Particles, Film & n.a \\
\hline Chou et al. (2007) & A & Electronic components & Film & $\mathrm{CO}_{2}$ \\
\hline Colder et al. (2004) & A & Electronic components & Particles & $\mathrm{CO}_{2}$ \\
\hline Combemale et al. (2009) & A & Electronic components & Particles & $\mathrm{CO}_{2}$ \\
\hline
\end{tabular}


Table 5 (continued)

\begin{tabular}{|c|c|c|c|c|}
\hline Sources & $\begin{array}{l}\text { Academia (A) } \\
\text { or Industry (I) }\end{array}$ & Fields & Functions & Lasers \\
\hline Costo et al. (2015) & $\mathrm{A}$ & Medical & Particles & n.a \\
\hline Costo et al. (2012) & A & Medical & Particles & $\mathrm{CO}_{2}$ \\
\hline Coupé et al. (2012) & I & Catalysts & Particles & $\mathrm{CO}_{2}$ \\
\hline Crisan et al. (2020) & A & Sensors & Particles & $\mathrm{CO}_{2}$ \\
\hline D’Amato et al. (2017) & A & Environment & Surface treatments & $\mathrm{CO}_{2}$ \\
\hline D’Amato et al. (2007) & A & Catalysts & Particles & $\mathrm{CO}_{2}$ \\
\hline Das et al. (2017) & A & Materials production & Particles, Measurements & $\mathrm{n} . \mathrm{a}$ \\
\hline David et al. (2006) & A & Materials production & Film & Diode \\
\hline David and Gaume (2015) & A & Materials production & Particles & $\mathrm{CO}_{2}$ \\
\hline de Araujo et al. (2017) & A & Batteries & Film & $\mathrm{CO}_{2}$ \\
\hline De Castro et al. (2011) & A & Catalysts & Particles, Film & $\mathrm{CO}_{2}$ \\
\hline De Castro et al. (2008) & A & Materials production & Particles & $\mathrm{CO}_{2}$ \\
\hline Depero et al. (2000) & A & Catalysts & Particles & n.a \\
\hline Dez et al. (2004) & A & Materials production & Particles, Film & $\mathrm{CO}_{2}$ \\
\hline Di Nunzio and Martelli (2006) & A & Materials production & Particles & $\mathrm{CO}_{2}$ \\
\hline Dinetz et al. (2002) & A & Catalysts & Syngas & Ion \\
\hline $\begin{array}{l}\text { Dohčević-Mitrović et al. } \\
\text { (2006) }\end{array}$ & A & Semiconductors & Particles & $\mathrm{Nd}$ \\
\hline Dumitrache et al. (2019) & A & Electronic components & Particles & n.a \\
\hline Dumitrache et al. (2005) & A & Catalysts & Particles, Film & $\mathrm{CO}_{2}$ \\
\hline Dumitrache et al. (2004) & A & Materials production & Film & $\mathrm{CO}_{2}$ \\
\hline Duty et al. (2003) & A & Precision manufacturing & Film, surface treatments & n.a \\
\hline Erogbogbo et al. (2011) & A & Solar cells & Particles & n.a \\
\hline Escamilla-Pérez et al. (2019) & I & Batteries & Film & n.a \\
\hline Fa et al. (2006) & A & Semiconductors & Particles & $\mathrm{CO}_{2}$ \\
\hline Falconieri et al. (2009) & A & Solar cells & Particles & n.a \\
\hline Figgemeier et al. (2007) & A & Solar cells & Film & $\mathrm{CO}_{2}$ \\
\hline Fleaca et al. (2016) & A & Catalysts & Particles & n.a \\
\hline Fleaca et al. (2015a) & A & Materials production & Particles & $\mathrm{CO}_{2}$ \\
\hline Fleaca et al. (2015b) & A & Catalysts & Particles & n.a \\
\hline Fleaca et al. (2014) & A & Supercapacitors & Particles & n.a \\
\hline Fleaca et al. (2013) & A & Catalysts & Particles & $\mathrm{CO}_{2}$ \\
\hline Florescu et al. (2007) & A & Medicine & Particles & $\mathrm{CO}_{2}$ \\
\hline Gadallah et al. (2013) & A & Aerospace & Particles & n.a \\
\hline Galvez et al. (2002) & A & Analysis & Particles, measurements & $\mathrm{CO}_{2}$ \\
\hline Gavrila-Florescu et al. (2017) & A & Medical & Particles & $\mathrm{CO}_{2}$ \\
\hline Gavrila-Florescu et al. (2007) & A & Materials production & Particles & $\mathrm{CO}_{2}$ \\
\hline Gilmour et al. (2016) & A & Materials production & Measurements & n.a \\
\hline Govender et al. (2014) & A & Electronic components & Film & $\mathrm{CO}_{2}$ \\
\hline Govender et al. (2011) & A & Catalysts & Film & $\mathrm{CO}_{2}$ \\
\hline Greenwood (2011) & A & Catalysts & Particles & Neodymium \\
\hline Greenwood et al. (2002) & A & Analysis & Measurements & Neodymium \\
\hline Grimes et al. (2000) & A & Catalysts & Particles & $\mathrm{CO}_{2}$ \\
\hline Guerrero et al. (2015) & A & Materials production & Surface treatments & Neodymium, $\mathrm{CO}_{2}$ \\
\hline Gueunier-Farret et al. (2006) & A & Semiconductors & Film & $\mathrm{CO}_{2}$ \\
\hline Han and Zettl (2002) & A & Analysis & Measurements & diode \\
\hline Herlin-Boime et al. (2004) & A & Catalysts & Particles & $\mathrm{CO}_{2}$ \\
\hline Herring et al. (2003) & A & Catalysts & Particles & $\mathrm{CO}_{2}$ \\
\hline Horcher et al. (2020) & I & Precision manufacturing & Film & Neodimium \\
\hline
\end{tabular}


Table 5 (continued)

\begin{tabular}{|c|c|c|c|c|}
\hline Sources & $\begin{array}{l}\text { Academia (A) } \\
\text { or Industry (I) }\end{array}$ & Fields & Functions & Lasers \\
\hline Huisken et al. (2003) & A & Displays & Particles & $\mathrm{CO}_{2}$ \\
\hline Huisken et al. (2002) & A & Displays & Particles & $\mathrm{CO}_{2}$ \\
\hline Huminic et al. (2020) & A & Catalysts & Syngas & $\mathrm{CO}_{2}$ \\
\hline Huminic et al. (2017) & A & Materials production & Particles & n.a \\
\hline Huminic et al. (2016) & A & Materials production & Measurements & $\mathrm{CO}_{2}$ \\
\hline Huminic et al. (2015) & A & Materials production & Particles & $\mathrm{CO}_{2}$ \\
\hline Ilie et al. (2018) & A & Catalysts & Ethylene & $\mathrm{CO}_{2}$ \\
\hline Ilie et al. (2017) & A & Analysis & Measurements & $\mathrm{CO}_{2}$ \\
\hline Ivan et al. (2019) & A & Catalysts & Particles, Film & n.a \\
\hline Jäger et al. (2009) & A & Environment & Particles, Drilling & $\mathrm{CO}_{2}$ \\
\hline Jäger et al. (2006) & A & Materials production & Particles & $\mathrm{CO}_{2}$ \\
\hline Jang et al. (2020) & A & Semiconductors & Particles & $\mathrm{CO}_{2}$ \\
\hline Jeong et al. (2017) & A & Superconductors & Film & n.a \\
\hline Kabashin et al. (2019) & A & Medical & Particles & Diode \\
\hline Kassiba et al. (2002) & A & Analysis & Measurements & $\mathrm{CO}_{2}$ \\
\hline Kawada et al. (2019) & I & Sensors & Particles, Drilling & n.a \\
\hline Khan et al. (2015) & I & Medical & Particles & n.a \\
\hline Kim et al. (2019a) & I & Batteries & Particles & n.a \\
\hline Kim et al. (2019b) & A & Batteries & Film & n.a \\
\hline Kim et al. (2017) & A & Batteries & Particles & n.a \\
\hline Kim et al. (2015) & A & Electronic components & Film & $\mathrm{CO}_{2}$ \\
\hline Kim et al. (2014) & A & Environment & Particles & $\mathrm{CO}_{2}$ \\
\hline Kim et al. (2014) & A & Batteries & Particles & $\mathrm{CO}_{2}$ \\
\hline Kintz et al. (2015) & A & Solar cells & Film & $\mathrm{CO}_{2}$ \\
\hline Kobayashi et al. (2011) & A & Precision manufacturing & Film & Ion \\
\hline Kobayashi et al. (2010) & A & Electronic components & Particles & Ion \\
\hline Kostecki et al. (2002) & A & Electronic components & Particles, Marking & n.a \\
\hline Krauss and Motz (2002) & A & Electronic components & Film & n.a \\
\hline Kruger et al. (2017) & A & Catalysts & Particles & $\mathrm{CO} 2$ \\
\hline Kushnir and Sandén (2008) & A & $\begin{array}{l}\text { Solar cells, Electronic com- } \\
\text { ponents }\end{array}$ & Particles & $\mathrm{CO} 2$ \\
\hline Kuzuya et al. (2002) & A & Analysis & Measurements & Neodimium \\
\hline Kwok and Chiu (2003) & A & Catalysts & Film & $\mathrm{CO}_{2}$ \\
\hline Laguna-Marco et al. (2014) & A & Electronic components & Particles & $\mathrm{CO}_{2}$ \\
\hline Leconte et al. (2007) & A & Medical & Particles & $\mathrm{CO}_{2}$ \\
\hline Leconte et al. (2006) & A & Materials production & Particles & $\mathrm{CO}_{2}$ \\
\hline Ledoux et al. (2009) & A & Electronic components & Film & $\mathrm{CO}_{2}$ \\
\hline Ledoux et al. (2002) & A & Catalysts & Particles & $\mathrm{CO}_{2}$ \\
\hline Ledoux et al. (2001) & A & Catalysts & Particles & $\mathrm{CO}_{2}$ \\
\hline Ledoux et al. (2000) & A & Catalysts & Particles & n.a \\
\hline Lee et al. (2013) & A & Solar cells, Medical & Particles & $\mathrm{CO}_{2}$ \\
\hline Lee et al. (2008) & A & Catalysts & Film & $\mathrm{CO}_{2}$ \\
\hline Li et al. (2004) & A & Materials production & Film & $\mathrm{CO}_{2}$ \\
\hline Li et al. (2003) & A & Semiconductors & Particles & $\mathrm{CO}_{2}$ \\
\hline Lin et al. (2014) & A & Electronic components & Particles & diode \\
\hline Liu et al. (2018) & A & Electronic components & Film & n.a \\
\hline Liu et al. (2017) & A & Materials production & Particles, Film & n.a \\
\hline Liu et al. (2000) & A & Analysis & Measurements & Neodymium \\
\hline Lomello et al. (2012) & A & Catalysts & Particles & No \\
\hline
\end{tabular}


Table 5 (continued)

\begin{tabular}{|c|c|c|c|c|}
\hline Sources & $\begin{array}{l}\text { Academia (A) } \\
\text { or Industry (I) }\end{array}$ & Fields & Functions & Lasers \\
\hline Ma et al. (2009) & $\mathrm{A}$ & Solar cells & Particles & $\mathrm{CO}_{2}$ \\
\hline Malekzadeh et al. (2020) & I & Materials production & Particles & n.a \\
\hline Malumbres et al. (2015) & $\mathrm{A}$ & Catalysts & Particles & n.a \\
\hline Malumbres et al. (2013) & A & Materials production & Particles & n.a \\
\hline Marosfői et al. (2007) & A & Analysis & Measurements & $\mathrm{CO}_{2}$ \\
\hline Martelli et al. (2000) & A & Materials production & Particles & $\mathrm{CO}_{2}$ \\
\hline Martin et al. (2008) & A & Electronic components & Particles & $\mathrm{CO}_{2}$ \\
\hline Martins et al. (2019) & A & Sensors, Food production & $\begin{array}{l}\text { Surface treatments, Measure- } \\
\text { ments }\end{array}$ & $\mathrm{CO}_{2}$ \\
\hline Martinez et al. (2018) & A & Catalysts & Particles & Ion \\
\hline Martìnez et al. (2012) & A & Materials production & Particles & $\mathrm{CO}_{2}$ \\
\hline Mas et al. (2020) & A & $\begin{array}{l}\text { Materials production, Cata- } \\
\text { lysts }\end{array}$ & Particles & $\mathrm{CO}_{2}$ \\
\hline Maskrot et al. (2006) & A & Catalysts & Particles & $\mathrm{CO}_{2}$ \\
\hline Masyuk et al. (2018) & A & Energy production & Syngas & $\mathrm{CO}_{2}$ \\
\hline Mathews et al. (2011) & A & Precision manufacturing & Film & Neodimium \\
\hline Mejías et al. (2008) & A & Medical & Particles & n.a \\
\hline Melhem et al. (2013) & $\mathrm{A}$ & Solar cells & Film & n.a \\
\hline Melhem et al. (2011) & A & Solar cells & Particles & n.a \\
\hline Meruva et al. (2004) & I & Analysis & Measurements & Neodymium \\
\hline Metz et al. (2004) & I & Analysis & Measurements & Neodymium \\
\hline Minnekhanov et al. (2017) & A & Catalysts & Particles & $\mathrm{CO}_{2}$ \\
\hline Morjan et al. (2012) & A & Medical & Particles & n.a \\
\hline Morjan et al. (2010) & A & Materials production & Particles, Film & $\mathrm{CO}_{2}$ \\
\hline Morjan et al. (2009) & A & Materials production & Particles & $\mathrm{CO}_{2}$ \\
\hline Morjan et al. (2003) & I & Catalysts & Particles & $\mathrm{CO}_{2}$ \\
\hline Murakami et al. (2003) & A & Analysis & Measurements & Neodimium \\
\hline Mwakikunga et al. (2008a) & A & Analysis & Particles, Film, Measurements & $\mathrm{CO}_{2}$ \\
\hline Mwakikunga et al. (2008b) & A & Catalysts & Particles & $\mathrm{CO}_{2}$ \\
\hline Ning et al. (2019) & A & Electronic components & Film & n.a \\
\hline Nurk et al. (2015) & A & Batteries & Film & n.a \\
\hline Orlanducci et al. (2004) & A & Catalysts & Particles & $\mathrm{CO}_{2}$ \\
\hline Park et al. (2012) & A & Solar cells & Particles & $\mathrm{CO}_{2}$ \\
\hline Petcu et al. (2000) & A & Catalysts & Toluene & $\mathrm{CO}_{2}$ \\
\hline Pignon et al. (2008) & A & Catalysts & Particles & $\mathrm{CO}_{2}$ \\
\hline Pokorná et al. (2004) & A & Materials production & Film & $\mathrm{CO}_{2}$ \\
\hline Popovici et al. (2007) & A & Sensors, Catalysts, Medical & Particles & $\mathrm{CO}_{2}$ \\
\hline Pourchez et al. (2012) & I & Medical & Particles & $\mathrm{CO}_{2}$ \\
\hline Pozio et al. (2014) & A & Batteries & Film & $\mathrm{CO}_{2}$ \\
\hline Prati et al. (2014) & A & Analysis & Measurements & n.a \\
\hline Qi-Chen et al. (2017) & A & Electronic components & Film & n.a \\
\hline Qiao et al. (2018) & A & Electronic components & Film & Diode \\
\hline Rahimi et al. (2016) & A & Sensors & Film & $\mathrm{CO}_{2}$ \\
\hline Réau et al. (2012) & $\mathrm{A}$ & Catalysts & Particles & $\mathrm{CO}_{2}$ \\
\hline Reynaud et al. (2001) & A & Environment & Measurements & $\mathrm{CO}_{2}$ \\
\hline Roberts et al. (2013) & A & Electronic components & Film & Solid state \\
\hline Rohani (2018) & A & Supercapacitors & Particles & n.a \\
\hline Rohani and Bae (2017) & A & Catalysts & Particles & $\mathrm{CO}_{2}$ \\
\hline Rufino et al. (2011) & A & Materials production & Particles & $\mathrm{CO}_{2}$ \\
\hline
\end{tabular}


Table 5 (continued)

\begin{tabular}{|c|c|c|c|c|}
\hline Sources & $\begin{array}{l}\text { Academia (A) } \\
\text { or Industry (I) }\end{array}$ & Fields & Functions & Lasers \\
\hline Russell and Yee (2005) & $\mathrm{A}$ & Analysis & Measurements & Neodymium \\
\hline Rybaltovskii et al. (2012) & A & Catalysts & Particles & n.a \\
\hline Sandu et al. (2004) & A & Precision manufacturing & Film & n.a \\
\hline Scarisoreanu et al. (2020) & A & environment & Particles & n.a \\
\hline Scarisoreanu et al. (2019) & A & Catalysts & Particles & n.a \\
\hline Scarisoreanu et al. (2017) & A & Electronic components & Film & $\mathrm{CO}_{2}$ \\
\hline Scarisoreanu et al. (2007) & A & Catalysts & Film & $\mathrm{CO}_{2}$ \\
\hline Schinteie et al. (2013) & A & Materials production & Particles & n.a \\
\hline Shimoda (2018) & A & Catalysts & Particles, Film & n.a \\
\hline Shin et al. (2020) & A & Precision manufacturing & Additive & $\mathrm{CO}_{2}$, excimer \\
\hline Simakin et al. (2000a) & A & Materials production & Film & Ion \\
\hline Simakin et al. (2000b) & A & Materials production & Film & Ion \\
\hline Simon et al. (2010) & A & Solar cells & Particles & $\mathrm{CO}_{2}$ \\
\hline Sourice et al. (2016) & $\mathrm{A}$ & Batteries & Particles & n.a \\
\hline Sourice et al. (2015) & A & batteries & Particles & $\mathrm{CO}_{2}$ \\
\hline Steglich et al. (2012) & $\mathrm{A}$ & Environment & Measurements & Neodymium \\
\hline Sublemontier et al. (2011) & A & Solar cells, Medical & Particles & $\mathrm{CO}_{2}$ \\
\hline Sublemontier et al. (2009) & A & Solar cells, Medical & Particles & $\mathrm{CO}_{2}$ \\
\hline Tangermann-Gerk et al. 2016 & I & Electronic components & Film & Neodimium \\
\hline Ténégal et al. (2001) & A & Catalysts & Particles & $\mathrm{CO}_{2}$ \\
\hline Ténégal et al. (2000) & A & Catalysts & Particles & $\mathrm{CO}_{2}$ \\
\hline Tiliakos et al. (2020) & A & n.a & Film & n.a \\
\hline Tiliakos et al. (2018) & A & Supercapacitors & Film & n.a \\
\hline Tiliakos et al. (2016) & A & Electronic components & Particles, Film & $\mathrm{CO}_{2}$ \\
\hline Tóth and Piglmayer (2004) & A & Batteries & Film, Drilling & n.a \\
\hline Vangelatos et al. (2020) & A & Precision manufacturing & Additive & Excimer \\
\hline van’t Zand, (2012) & A & Medical & Particles & Diode \\
\hline $\begin{array}{l}\text { Veintemillas-Verdaguer et al. } \\
\text { (2003) }\end{array}$ & A & Medical & Particles & $\mathrm{CO}_{2}$ \\
\hline $\begin{array}{l}\text { Veintemillas-Verdaguer et al. } \\
\text { (2002) }\end{array}$ & A & Materials production & Particles & $\mathrm{CO}_{2}$ \\
\hline $\begin{array}{l}\text { Veintemillas-Verdaguer et al. } \\
\text { (2001) }\end{array}$ & A & Catalysts & Particles & $\mathrm{CO}_{2}$ \\
\hline Vladimirov et al. (2014) & A & Catalysts & Particles & $\mathrm{CO}_{2}$ \\
\hline Vladimirov et al. (2011) & A & Catalysts & Particles & $\mathrm{CO}_{2}$ \\
\hline Wang et al. (2019) & A & Food production & Particles & n.a \\
\hline Wang et al. (2017) & A & Batteries & Particles & n.a \\
\hline Wang et al. (2015) & A & Solar cells & Particles & n.a \\
\hline Watanabe et al. (2005) & A & Catalysts & Film & n.a \\
\hline Watanabe et al. (2003) & I & Materials production & Film & Neodymium \\
\hline Watanabe et al. (2002) & A & Catalysts & Film & $\mathrm{CO}_{2}$ \\
\hline Wei and Xu (2012) & I & Materials production & Measurements & n.a \\
\hline Wilden and Fischer (2007) & A & Catalysts & Particles & Neodymium \\
\hline $\mathrm{Xu}$ and $\mathrm{Hu}(2017)$ & I & Catalysts & Particles & Yb, fiber, diode \\
\hline Xue et al. (2016) & A & Materials production & Film & n.a \\
\hline Yeon et al. (2019) & $\mathrm{A}$ & Fuel cells & Particles, Film & $\mathrm{CO}_{2}$ \\
\hline $\begin{array}{l}\text { Yoshioka and Ishiwatari } \\
(2002)\end{array}$ & A & Analysis & Measurements & $\mathrm{CO}_{2}$ \\
\hline Zhao et al. (2017) & A & Materials production & Film & n.a \\
\hline Zhao et al. (2001) & A & Electronic components & Particles & $\mathrm{CO}_{2}$ \\
\hline
\end{tabular}


Table 5 (continued)

\begin{tabular}{|c|c|c|c|c|}
\hline Sources & $\begin{array}{l}\text { Academia (A) } \\
\text { or Industry (I) }\end{array}$ & Fields & Functions & Lasers \\
\hline \multicolumn{5}{|l|}{ Patents } \\
\hline AT544513 & I & Electronic components & Particles & n.a \\
\hline BR102013031976 & A & Catalysts & Syngas, Hydrogen & $\mathrm{CO}_{2}$ \\
\hline CN101215161 & I & Electronic components & Particles & Neodimium \\
\hline CN101318657 & I & Electronic components & Particles & Neodymium \\
\hline CN102676197 & I & $\begin{array}{l}\text { Environment, Energy produc- } \\
\text { tion }\end{array}$ & Oil, Measurements & n.a \\
\hline CN103630669 & I & Catalysts, Environment & Oil, Syngas, Measurements & n.a \\
\hline CN104198381 & A & Catalysts & Oil & n.a \\
\hline CN105288621 & A & Medical & Film & $\mathrm{CO}_{2}$ \\
\hline CN105821400 & I & Catalysts & Film & Diode \\
\hline CN106083059 & A & $\begin{array}{l}\text { Aerospace, Electronic com- } \\
\text { ponents }\end{array}$ & Particles, Additive & n.a \\
\hline CN106644722 & I & n.a & Particles, Drilling & n.a \\
\hline CN107043259 & I & Catalysts & Particles, Additive & $\mathrm{CO}_{2}$ \\
\hline CN107838172 & I & Energy production & $\begin{array}{l}\text { Syngas, Generating electricity, } \\
\text { Eliminating waste }\end{array}$ & Neodymium \\
\hline CN108281490 & A & Electronic components & Particles, Film & Neodymium \\
\hline CN108414035 & A & Electronic components & Film, Cutting & Neodymium \\
\hline CN108465814 & I & Materials production & Particles, Additive & $\mathrm{CO}_{2}$ \\
\hline CN109052889 & I & Waste & Eliminating waste & n.a \\
\hline CN109128163 & A & $\begin{array}{l}\text { Materials production, aero- } \\
\text { space }\end{array}$ & Particles, Additive & n.a \\
\hline CN109402615 & I & $\begin{array}{l}\text { Semiconductors, Electronic } \\
\text { components }\end{array}$ & Film & Diode \\
\hline CN110372390 & A & Semiconductors & Film, Additive & n.a \\
\hline CN110451755 & I & Energy production & Eliminating waste & n.a \\
\hline CN110512193 & I & Energy production & Particles, Additive & Neodymium \\
\hline CN110518256 & A & Materials production & $\begin{array}{l}\text { Film, Marking, Surface treat- } \\
\text { ments }\end{array}$ & Neodymium \\
\hline CN110520381 & A & Waste & Film & Excimer \\
\hline CN110548174 & A & Energy production & Eliminating waste & n.a \\
\hline CN110632165 & A & Energy production & Eliminating waste & n.a \\
\hline CN111018537 & A & Materials production & Particles, Additive & n.a \\
\hline CN111283334 & I & $\begin{array}{l}\text { Materials production, Preci- } \\
\text { sion manufacturing }\end{array}$ & Film, Cutting & n.a \\
\hline CN111403691 & I & batteries & Film, Cutting & $\mathrm{CO}_{2}$ \\
\hline CN1428193 & A & Catalysts & Particles, Ethylene, Propene & $\mathrm{CO}_{2}$ \\
\hline CN201735397 & A & Catalysts & Syngas, Hydrogen & $\mathrm{CO}_{2}$ \\
\hline CN204086108 & A & Solar cells & Oil & n.a \\
\hline DE10296273 & I & Electronic components & Particles & $\mathrm{CO}_{2}$ \\
\hline DE60144572 & I & $\begin{array}{l}\text { Electronic components, } \\
\text { Memories }\end{array}$ & Marking & Excimer \\
\hline EP1697257 & I & Catalysts & Particles & $\mathrm{CO}_{2}$ \\
\hline EP2040772 & I & Medical & Film & $\mathrm{CO}_{2}$ \\
\hline EP2183058 & I & Catalysts & Particles & $\mathrm{CO}_{2}$ \\
\hline EP2889271 & I & $\begin{array}{l}\text { Fuel cells, Materials produc- } \\
\text { tion }\end{array}$ & Particles, Oil & $\mathrm{CO}_{2}$ \\
\hline EP2889272 & I & $\begin{array}{l}\text { Fuel cells, Materials produc- } \\
\text { tion }\end{array}$ & Particles, Oil & $\mathrm{CO}_{2}$ \\
\hline EP2922626 & I & Biomedical & Particles & n.a \\
\hline
\end{tabular}


Table 5 (continued)

\begin{tabular}{|c|c|c|c|c|}
\hline Sources & $\begin{array}{l}\text { Academia (A) } \\
\text { or Industry (I) }\end{array}$ & Fields & Functions & Lasers \\
\hline EP3246436 & I & $\begin{array}{l}\text { Batteries, Fuel cells, Elec- } \\
\text { tronic components }\end{array}$ & Film & $\mathrm{CO}_{2}$ \\
\hline EP3395437 & I & Electronic components & Particles & $\mathrm{CO}_{2}$ \\
\hline US10023813 & A & Catalysts & Particles & $\mathrm{CO}_{2}$ \\
\hline FR2920965 & $\mathrm{I}$ & Catalysts & Particles, Syngas & n.a \\
\hline FR2937419 & I & Semiconductors & Particles & $\mathrm{CO}_{2}$ \\
\hline FR2984758 & I & $\begin{array}{l}\text { Catalysts, Materials produc- } \\
\text { tion }\end{array}$ & Particles & Fiber \\
\hline FR2984766 & I & Materials production & Particles & Fiber \\
\hline FR2984867 & I & Materials production & Particles & $\mathrm{CO}_{2}$ \\
\hline FR3082768 & I & Batteries & Particles & $\mathrm{CO}_{2}$ \\
\hline JP2002255525 & I & Superconductors & Film & n.a \\
\hline JP2002274950 & I & Superconductors & Film, Drilling & Diode \\
\hline JP2002313147 & I & Semiconductors & Film & Excimer \\
\hline JP2003342013 & I & Electronic components & Film & $\mathrm{CO}_{2}$ \\
\hline JP2006256294 & I & Memories & Film & Diode \\
\hline JP2013021251 & I & Semiconductors & Film, Marking & $\mathrm{CO}_{2}$ \\
\hline JP2019079659 & I & Batteries & Film & $\mathrm{CO}_{2}$, fiber, neodymium, diode \\
\hline JP3962283 & I & Semiconductors & Film & Diode, krypton \\
\hline JP4344629 & I & Electronic components & $\begin{array}{l}\text { Particles, Film, Surface treat- } \\
\text { ments }\end{array}$ & Diode \\
\hline JP4629663 & I & $\begin{array}{l}\text { Catalysts, Precision manufac- } \\
\text { turing }\end{array}$ & $\begin{array}{l}\text { Particles, Cutting, Measure- } \\
\text { ments }\end{array}$ & n.a \\
\hline JP4799459 & I & n.a & Film, Marking & Neodimium \\
\hline JP4833082 & I & Food production & Particles & $\mathrm{CO}_{2}$ \\
\hline JP4963062 & I & Memories & Film & Neodymium \\
\hline JP5066686 & I & Superconductors & Film & Neodymium \\
\hline JP6257682 & I & Displays, Solar cells & Particles & $\mathrm{CO}_{2}$ \\
\hline KR100893183 & I & Catalysts & Particles & $\mathrm{CO}_{2}$ \\
\hline KR101839212 & A & Displays & Film & $\mathrm{CO}_{2}$ \\
\hline KR101841558 & I & Catalysts & Particles & $\mathrm{CO}_{2}$ \\
\hline KR10-1918935 & A & Catalysts & Particles & $\mathrm{CO}_{2}$ \\
\hline KR10-2002853 & A & Batteries & Particles & n.a \\
\hline KR10-2020-0010739 & A & Electronic components & Particles & $\mathrm{CO}_{2}$ \\
\hline KR10-2118865 & I & Catalysts & Particles & $\mathrm{CO}_{2}$ \\
\hline KR20120084193 & A & Electronic components & Film & $\mathrm{n} . \mathrm{a}$ \\
\hline KR20170121985 & I & Electronic components & Particles & n.a \\
\hline WO2006/051233 & I & Electronic components & Particles & $\mathrm{CO}_{2}$ \\
\hline PL1963004 & I & Materials production & Particles & $\mathrm{CO}_{2}$ \\
\hline RO126660 & I & $\begin{array}{l}\text { Electronic components, Medi- } \\
\text { cal }\end{array}$ & Particles & n.a \\
\hline RO129669 & I & & Particles & $\mathrm{CO}_{2}$ \\
\hline RO130505 & I & Electronic components & Particles & $\mathrm{n} . \mathrm{a}$ \\
\hline RO131386 & I & $\begin{array}{l}\text { Electronic components, Medi- } \\
\text { cal }\end{array}$ & Particles & $\mathrm{CO}_{2}$, diode \\
\hline RO131387 & I & $\begin{array}{l}\text { Electronic components, Medi- } \\
\text { cal }\end{array}$ & Particles & n.a \\
\hline RO131388 & I & $\begin{array}{l}\text { Electronic components, Medi- } \\
\text { cal }\end{array}$ & Particles & n.a \\
\hline RO131389 & I & Electronic components & Particles & n.a \\
\hline RO131436 & I & Medical & Particles & $\mathrm{CO}_{2}$, neodymium \\
\hline
\end{tabular}


Table 5 (continued)

\begin{tabular}{|c|c|c|c|c|}
\hline Sources & $\begin{array}{l}\text { Academia (A) } \\
\text { or Industry (I) }\end{array}$ & Fields & Functions & Lasers \\
\hline RO131631 & I & Analysis & Particles & $\mathrm{CO}_{2}$, diode \\
\hline RO131728 & I & Analysis & Particles & $\mathrm{CO}_{2}$ \\
\hline RO131729 & I & Analysis & Particles & $\mathrm{CO}_{2}$, diode \\
\hline RO132432 & A & Catalysts & Film & Neodymium \\
\hline RO133164 & I & $\begin{array}{l}\text { Materials production, Cata- } \\
\text { lysts }\end{array}$ & Film & Neodymium \\
\hline RO133406 & I & Materials production & Particles, Film, Additive & $\mathrm{CO}_{2}$ \\
\hline RU145336 & I & Analysis & Measurements & $\mathrm{CO}_{2}$ \\
\hline RU2252280 & I & Catalysts & $\begin{array}{l}\text { Film, Marking, Surface treat- } \\
\text { ments }\end{array}$ & n.a \\
\hline RU2326994 & I & Semiconductors & Particles & Diode \\
\hline RU2403499 & I & Catalysts & Syngas, Oil & n.a \\
\hline RU2414420 & I & Materials production & Particles & Neodymium \\
\hline RU2472870 & I & Electronic components & Film & n.a \\
\hline RU2478398 & I & Medical & Film, Additive & n.a \\
\hline RU2602568 & I & n.a & Particles & n.a \\
\hline TW201802868 & I & Semiconductors & Particles & Neodymium \\
\hline UA26961 & A & Materials production & Particles, Film, Additive & $\mathrm{CO}_{2}$ \\
\hline US10054577 & I & Environment & Measurements & n.a \\
\hline US10160650 & I & $\begin{array}{l}\text { Electronic components, medi- } \\
\text { cal }\end{array}$ & Particles, Additive & n.a \\
\hline US10199177 & A & $\begin{array}{l}\text { Electronic components, solar } \\
\text { cells }\end{array}$ & Particles & $\mathrm{CO}_{2}$ \\
\hline US10598012 & I & Environment & Cutting, Measurements & Fiber \\
\hline US10673062 & I & $\begin{array}{l}\text { Electronic components, bat- } \\
\text { teries }\end{array}$ & Particles & $\mathrm{CO}_{2}$ \\
\hline US20060225534 & I & $\begin{array}{l}\text { Medical, Electronic compo- } \\
\text { nents }\end{array}$ & Particles, Film, Toluene & $\mathrm{CO}_{2}$ \\
\hline US20070023038 & I & Medical & Particles, Film & n.a \\
\hline US20080008216 & I & Semiconductors & Film & Diode \\
\hline US20100006187 & I & Materials production & $\begin{array}{l}\text { Surface finishing, Plastic } \\
\text { deforming, Measurements }\end{array}$ & $\mathrm{n} . \mathrm{a}$ \\
\hline US20100308286 & A & $\begin{array}{l}\text { Electronic components, Solar } \\
\text { cells }\end{array}$ & Particles & Diode \\
\hline US20120128542 & I & Semiconductors & Particles & $\mathrm{CO}_{2}$ \\
\hline US20190388865 & I & Catalysts & Particles & $\mathrm{CO}_{2}$ \\
\hline US20200227884 & I & Electronic components & Film, cutting & Diode \\
\hline US7601321 & I & Semiconductors & Particles, surface treatments & $\mathrm{CO}_{2}$ \\
\hline US8054558 & I & Displays & n.a & n.a \\
\hline US9096440 & I & Superconductors, memories & Film & Neodymium \\
\hline WO2008/118865 & I & Semiconductors & Particles & $\mathrm{CO}_{2}$ \\
\hline WO2008/143716 & I & Semiconductors & Particles & $\mathrm{CO}_{2}$ \\
\hline WO2012/175462 & I & Catalysts & Particles & $\mathrm{CO}_{2}$ \\
\hline WO2015/183122 & I & Catalysts & Olefins, Hydrogen & $\mathrm{CO}_{2}$ \\
\hline WO2017/039477 & I & Catalysts & Particles, Ethylene, Hydrogen, & $\mathrm{CO}_{2}$ \\
\hline WO2019/159088 & A & Energy production & $\begin{array}{l}\text { Syngas, Hydrogen, Oil, Elimi- } \\
\text { nating waste }\end{array}$ & $\mathrm{CO}_{2}$ \\
\hline
\end{tabular}


Authors' contributions Article idea: C.S.; literature search and data analysis: C.S.; writing - original draft preparation: C.S. and D.R.; writing—review and editing: C.S., D.R., R.D.I.; Supervision: D.R.

Funding Open access funding provided by Università degli studi di Bergamo within the CRUI-CARE Agreement. This research received no external funding.

\section{Availability of data and material Not applicable.}

Code availability Not applicable.

\section{Declarations}

Conflicts of interest The authors declare no conflict of interest.

Open Access This article is licensed under a Creative Commons Attribution 4.0 International License, which permits use, sharing, adaptation, distribution and reproduction in any medium or format, as long as you give appropriate credit to the original author(s) and the source, provide a link to the Creative Commons licence, and indicate if changes were made. The images or other third party material in this article are included in the article's Creative Commons licence, unless indicated otherwise in a credit line to the material. If material is not included in the article's Creative Commons licence and your intended use is not permitted by statutory regulation or exceeds the permitted use, you will need to obtain permission directly from the copyright holder. To view a copy of this licence, visit http://creativecommons.org/licenses/by/4.0/.

\section{References}

Abd Elrahman, A. A., \& Mansour, F. R. (2019). Targeted magnetic iron oxide nanoparticles: Preparation, functionalization and biomedical application. Journal of Drug Delivery Science and Technology, 52, 702-712.

Ahlhelm, M., Richter, H. J., \& Haderk, K. (2013). Selective laser sintering as an additive manufacturing method for manufacturing ceramic components. Journal of Ceramic Science and Technology, 4(1), 33-40.

Al Sandouk-Lincke, N. A., Schwarzbauer, J., Volk, H., HartkopfFröder, C., Fuentes, D., Young, M., \& Littke, R. (2013). Alteration of organic material during maturation: A pyrolytic and infrared spectroscopic study of isolated bisaccate pollen and total organic matter (Lower Jurassic, Hils Syncline, Germany). Organic Geochemistry, 59, 22-36.

Alexandrescu, R., Morjan, I., Scarisoreanu, M., Birjega, R., Fleaca, C., Soare, I., Gavrila, L., Ciupina, V., Kylberg, W., \& Figgemeier, E. (2010a). Development of the IR laser pyrolysis for the synthesis of iron-doped $\mathrm{TiO}_{2}$ nanoparticles: Structural properties and photoactivity. Infrared Physics \& Technology, 53(2), 94-102.

Alexandrescu, R., Morjan, I., Tomescu, A., Simion, C. E., Scarisoreanu, M., Birjega, R., Fleaca, C., Gavrila, L., Soare, I., Dumitrache, F., \& Prodan, G. (2010b). Direct production of a novel iron-based nanocomposite from the laser pyrolysis of mixtures: Structural and sensing properties. Journal of Nanomaterials, 2010,1-12.

Alexandrescu, R., Scarisoreanu, M., Morjan, I., Birjega, R., Fleaca, C., Luculescu, C., Soare, I., Cretu, O., Negrila, C. C., Lazarescu, N., \& Ciupina, V. (2009). Preparation and characterization of nitrogen-doped $\mathrm{TiO}_{2}$ nanoparticles by the laser pyrolysis of
$\mathrm{N}_{2} \mathrm{O}$-containing gas mixtures. Applied Surface Science, 255(10), 5373-5377.

Alexandrescu, R., Dumitrache, F., Morjan, I., Sandu, I., Savoiu, M., Voicu, I., Fleaca, C., \& Piticescu, R. (2004). $\mathrm{TiO}_{2}$ nanosized powders by $\mathrm{TiCl}_{4}$ laser pyrolysis. Nanotechnology, 15(5), 537.

Allen, G. R., \& Russell, D. K. (2004). Laser pyrolysis studies of the thermal decomposition of chlorinated organic compounds. Part 1-Acyl chlorides. New Journal of Chemistry, 28(9), 1107-1115.

Allen, G. R., \& Russell, D. K. (2002). Oxygen abstraction by laser pyrolysis of $\mathrm{W}(\mathrm{CO})_{6}$; A mild route to gas-phase carbene chemistry. Chemical Communications, 17, 1960-1961.

Alper, J. P. (2017). Laser pyrolysis derived silicon-carbon core-shell nanomaterials for lithium ion battery anodes. In Gordon conference nanomaterials for applications in energy technology, Feb 2017, Venturi Beach, United States. ffcea-02342075f.

Aminuzzaman, M., Watanabe, A., \& Miyashita, T. (2010). Direct writing of conductive silver micropatterns on flexible polyimide film by laser-induced pyrolysis of silver nanoparticle-dispersed film. Journal of Nanoparticle Research, 12(3), 931-938.

Aminuzzaman, M., Watanabe, A., \& Miyashita, T. (2009). Fabrication of conductive silver micropatterns on an organic-inorganic hybrid film by laser direct writing. Thin Solid Films, 517(20), 5935-5939.

Aminuzzaman, M., Watanabe, A., \& Miyashita, T. (2008). Photochemical surface modification and characterization of double-deckershaped polysilsesquioxane hybrid thin films. Journal of Materials Chemistry, 18(42), 5092-5097.

Bachmatiuk, A., Bystrzejewski, M., Schäffel, F., Ayala, P., Wolff, U., Mickel, C., Gemming, T., Pichler, T., Borowiak-Palen, E., Klingeler, R., Hübers, H.-W., Ulbrich, M., Knupfer, M., Haberer, D., Büchner, B., \& Rümmeli, M. H. (2009). Carbon nanotube synthesis via ceramic catalysts. Physica Status Solidi (b), 246(11-12), 2486-2489.

Badoi, A. D., Dumitrache, F., Fleaca, C. T., Mihailescu, N., Vasile, E., Luculescu, C., Gavrila, L., Morjan, I., \& Ciuca, I. (2016). The influence of 1,3-diaminopropane in functional groups generation on iron oxide nanoparticles surfaces synthesized by laser pyrolysis. Optoelectronics and Advanced Materials-Rapid Communications, 10, 16-20.

Bădoi, A. D., Bărbuţ, I., Butoi, B., Dănilă, O., Ganciu, M., Luculescu, C., Morjan, I., Fleacă, C., Dumitrache, F., Gavrilă, L., Vasile, E., Mihăilescu, N., Cucu, A., \& Ciucă, I. (2015). Covering with chitosan and hyaluronic acid shells of iron based nanoparticles obtained by laser pyrolysis for medical applications. University Politehnica of Bucarest Scientific Bulletin Series B-Chemistry and Materials Science, 77(3), 207-220.

Bahgat, M. (2006). Technology of iron carbide synthesis. Journal of Materials Science and Technology, 22(3), 423.

Baia, M., Scarisoreanu, M., Morjan, I., Morjan, I. P., Baia, L., Cosoveanu, V., Alexandrescu, R., \& Danciu, V. (2011). Morphostructural characterization of $\mathrm{TiO}_{2}$ nanosized powders with photocatalytic potential. Studia Universitatis Babes-Bolyai, Chemia, 56(3), 5-13.

Balas, M., Dumitrache, F., Badea, M. A., Fleaca, C., Badoi, A., Tanasa, E., \& Dinischiotu, A. (2018). Coating dependent in vitro biocompatibility of new Fe-Si nanoparticles. Nanomaterials, 8(7), 495.

Barrault, J., Valange, S., Tatibouet, J. M., Thollon, S., Herlin-Boime, N., Giraud, S., Ruiz, J. C., Bergaya, B., Joulin, J. P., Delbianco, N., \& Gabelica, Z. (2009). Synthesis of supported metallic nanoparticles and their use in air depollution. Actualite Chimique, $331,20-29$.

Baskakov, A. O., Lyubutin, I. S., Starchikov, S. S., Davydov, V. A., Kulikova, L. F., Egorova, T. B., \& Agafonov, V. N. (2018). Mechanism of transformation of ferrocene into carbon-encapsulated iron carbide nanoparticles at high pressures and temperatures. Inorganic Chemistry, 57(23), 14895-14903. 
Baymler, I. V., Barmina, E. V., Simakin, A. V., \& Shafeev, G. A. (2018). Generation of hydrogen under laser irradiation of organic liquids. Quantum Electronics, 48(8), 738.

Belchi, R., Habert, A., Foy, E., Gheno, A., Vedraine, S., Antony, R., Ratier, B., Bouclé, J., \& Herlin-Boime, N. (2019). One-step synthesis of $\mathrm{TiO}_{2}$ /graphene nanocomposites by laser pyrolysis with well-controlled properties and application in perovskite solar cells. ACS Omega, 4(7), 11906-11913.

Bhattacharjya, D., Kim, C. H., Kim, J. H., You, I. K., In, J. B., \& Lee, S. M. (2018). Fast and controllable reduction of graphene oxide by low-cost $\mathrm{CO}_{2}$ laser for supercapacitor application. Applied Surface Science, 462, 353-361.

Bodzay, B., Marosfoi, B. B., Igricz, T., Bocz, K., \& Marosi, G. (2009). Polymer degradation studies using laser pyrolysis-FTIR microanalysis. Journal of Analytical and Applied Pyrolysis, 85(1-2), 313-320.

Bomatí-Miguel, O., Mazeina, L., Navrotsky, A., \& Veintemillas-Verdaguer, S. (2008). Calorimetric study of maghemite nanoparticles synthesized by laser-induced pyrolysis. Chemistry of Materials, 20(2), 591-598.

Bomatí-Miguel, O., Tartaj, P., Morales, M. P., Bonville, P., GollaSchindler, U., Zhao, X. Q., \& Veintemillas-Verdaguer, S. (2006). Core-shell iron-iron oxide nanoparticles synthesized by laserinduced pyrolysis. Small (weinheim an Der Bergstrasse, Germany), 2(12), 1476-1483.

Bomatí-Miguel, O., Morales, M. P., Tartaj, P., Ruiz-Cabello, J., Bonville, P., Santos, M., Zhao, X., \& Veintemillas-Verdaguer, S. (2005). Fe-based nanoparticulate metallic alloys as contrast agents for magnetic resonance imaging. Biomaterials, 26(28), $5695-5703$.

Botti, S., Terranova, M. L., Sessa, V., Piccirillo, S., \& Rossi, M. (2001). Silicon quantum dots in diamond matrix: A new synthesis route. Applied Organometallic Chemistry, 15(5), 388-392.

Bouclé, J., Herlin-Boime, N., \& Kassiba, A. (2005). Influence of silicon and carbon excesses on the aqueous dispersion of SiC nanocrystals for optical application. Journal of Nanoparticle Research, $7(2), 275-285$.

Bouhadoun, S., Guillard, C., Sorgues, S., Hérissan, A., Colbeau-Justin, C., Dapozze, F., Habert, A., Maurel, V., \& Herlin-Boime, N. (2017). Laser synthesized $\mathrm{TiO}_{2}$-based nanoparticles and their efficiency in the photocatalytic degradation of linear carboxylic acids. Science and Technology of Advanced MaTerialS, 18(1), 805-815.

Bouhadoun, S., Guillard, C., Dapozze, F., Singh, S., Amans, D., Bouclé, J., \& Herlin-Boime, N. (2015). One step synthesis of $\mathrm{N}$-doped and $\mathrm{Au}$-loaded $\mathrm{TiO}_{2}$ nanoparticles by laser pyrolysis: Application in photocatalysis. Applied Catalysis B: Environmental, 174, 367-375.

Bourrioux, S., Wang, L. P., Rousseau, Y., Simon, P., Habert, A., Leconte, Y., Sougrati, M. T., Stievano, L., Monconduit, L., Xu, Z. J., Srinivasan, M., \& Pasturel, A. (2017). Evaluation of electrochemical performances of $\mathrm{ZnFe}_{2} \mathrm{O}_{4} / \gamma-\mathrm{Fe}_{2} \mathrm{O}_{3}$ nanoparticles prepared by laser pyrolysis. New Journal of Chemistry, 41(17), 9236-9243.

Bridgwater, A. V. (2012). Review of fast pyrolysis of biomass and product upgrading. Biomass and Bioenergy, 38, 68-94.

Bystrzejewski, M., Hübers, H. W., Huczko, A., Gemming, T., Büchner, B., \& Rümmeli, M. H. (2009). Bulk synthesis of carbon nanocapsules and nanotubes containing magnetic nanoparticles via low energy laser pyrolysis of ferrocene. Materials Letters, 63(21), 1767-1770.

Bystrzejewski, M., Lange, H., Huczko, A., Baranowski, P., Hübers, H. W., Gemming, T., Pichler, T., Büchner, B., \& Rümmeli, M. H. (2008). One-step catalyst-free generation of carbon nanospheres via laser-induced pyrolysis of anthracene. Journal of Solid State Chemistry, 181(10), 2796-2803.
Chen, J., Rohani, P., Karakalos, S. G., Lance, M. J., Toops, T. J., Swihart, M. T., \& Kyriakidou, E. A. (2020). Boron-hyperdoped silicon for the selective oxidative dehydrogenation of propane to propylene. Chemical Communications, 56(68), 9882-9885.

Chen, X., Yagi, M., Akiyama, Y., Machida, O., Ohta, E., Meixner, M., Stollenwerk, J., Boettger, U., \& Schneller, T. (2013). Fabrication of multilayer $\mathrm{Pb}\left(\mathrm{Zr}_{0.53} \mathrm{Ti}_{0.47}\right) \mathrm{O}_{3}$ film crystallized by laser annealing. Japanese Journal of Applied Physics, 52(9S1), 09KA06.

Chen, X., \& Mao, S. S. (2006). Synthesis of titanium dioxide (TiO2) nanomaterials. Journal of Nanoscience and Nanotechnology, 6(4), 906-925.

Chizhik, A. M., Chizhik, A. I., Gutbrod, R., Meixner, A. J., Schmidt, T., Sommerfeld, J., \& Huisken, F. (2009). Imaging and spectroscopy of defect luminescence and electron-phonon coupling in single $\mathrm{SiO}_{2}$ nanoparticles. Nano Letters, 9(9), 3239-3244.

Choi, H. S., Kim, S. J., Choi, H. W., Park, C. E., Gao, Y. J., Hang, Y., Jeong, S. Y., Kim, J. P., Bae, J. S., \& Cho, C. R. (2017). Enhanced cycle stability of silicon nanoparticles coated with nitrogen-doped carbon layer for lithium-ion battery anode. Current Applied Physics, 17(8), 1087-1093.

Chou, C. C., Tsai, S. D., Tu, W. H., Yeh-Liu, Y. E., \& Tsai, H. L. (2007). Low-temperature processing of sol-gel derived $\mathrm{Pb}(\mathrm{Zr}, \mathrm{Ti})$ $\mathrm{O}_{3}$ thick films using $\mathrm{CO}_{2}$ laser annealing. Journal of Sol-Gel Science and Technology, 42(3), 315-322.

Colder, A., Huisken, F., Trave, E., Ledoux, G., Guillois, O., Reynaud, C., Hofmeister, H., \& Pippel, E. (2004). Strong visible photoluminescence from hollow silica nanoparticles. Nanotechnology, 15(3), L1.

Combemale, L., Leconte, Y., Portier, X., Herlin-Boime, N., \& Reynaud, C. (2009). Synthesis of nanosized zirconium carbide by laser pyrolysis route. Journal of Alloys and Compounds, 483(12), 468-472.

Costo, R., Bello, V., Robic, C., Port, M., Marco, J. F., Puerto Morales, M., \& Veintemillas-Verdaguer, S. (2012). Ultrasmall iron oxide nanoparticles for biomedical applications: Improving the colloidal and magnetic properties. Langmuir, 28(1), 178-185.

Costo, R., Morales, M. P., \& Veintemillas-Verdaguer, S. (2015). Improving magnetic properties of ultrasmall magnetic nanoparticles by biocompatible coatings. Journal of Applied Physics, 117(6), 064311.

Coupé, A., Maskrot, H., Buet, E., Renault, A., Fontaine, P. J., \& Chaffron, L. (2012). Dispersion behaviour of laser-synthesized silicon carbide nanopowders in ethanol for electrophoretic infiltration. Journal of the European Ceramic Society, 32(14), 3837-3850.

Crisan, O., Crisan, A. D., Dumitrache, F., \& Luculescu, C. (2020). Hybrid nanoelectronic-magnetic device with magnetoresistive core-shell Fe/FeC nanoparticles. Applied Physics A, 126(3), 1-9.

D’Amato, R., Spizzichino, V., Caneve, L., Bonfigli, F., Giancristofaro, C., \& Persia, F. (2017). Nanomaterials for conservation of artistic stones: performance and removal tests by laser cleaning. In Journal of nano research (Vol. 46, pp. 225-233). Trans Tech Publications Ltd.

D’Amato, R., Falconieri, M., Carpanese, M., Fabbri, F., \& Borsella, E. (2007). Strong luminescence emission enhancement by wet oxidation of pyrolytic silicon nanopowders. Applied Surface Science, 253(19), 7879-7883.

Das, G., Kumar, M., Biswas, A. K., Khooha, A., Mondal, P., \& Tiwari, M. K. (2017, May). Determination of surface morphology of $\mathrm{TiO} 2$ nanostructure using synchrotron radiation. In AIP conference proceedings (Vol. 1832, No. 1, p. 050025). AIP Publishing LLC.

de Castro, V., Benito, G., Hurst, S., Serna, C. J., Morales, M. P., \& Veintemillas-Verdaguer, S. (2011). One step production of magnetic nanoparticle films by laser pyrolysis inside a chemical vapour deposition reactor. Thin Solid Films, 519(22), 7677-7682. 
de Castro, V., Benito, G., Hurst, S., Cebollada, F., Serna, C. J., Morales, M. P., \& Veintemillas-Verdaguer, S. (2008). Functionalisation of glass with iron oxide nanoparticles produced by laser pyrolysis. Journal of Nanoscience and Nanotechnology, 8(5), 2458-2462.

Dez, R., Porterat, D., \& Boime, N. H. (2004). Silicon carbonitride nanopowders by laser pyrolysis for plastic nanocomposites. In Key engineering materials (Vol. 264, pp. 25-28). Trans Tech Publications Ltd.

David, B., Schneeweiss, O., Pizúrová, N., Klementová, M., Bezdička, P., Alexandrescu, R., Dumitrache, F., \& Morjan, I. (2006). Fe3C nanopowder synthesized by laser pyrolysis and its annealing behaviour. Surface and Interface Analysis: An International Journal Devoted to the Development and Application of Techniques for the Analysis of Surfaces, Interfaces and Thin Films, 38(4), 482-485.

David, S. P., \& Gaume, R. (2015). Electroluminescent thin film phosphors. In Thin film structures in energy applications (pp. 243269). Springer, Cham.

de Araujo, W. R., Frasson, C. M., Ameku, W. A., Silva, J. R., Angnes, L., \& Paixão, T. R. (2017). Single-step reagentless laser scribing fabrication of electrochemical paper-based analytical devices. Angewandte Chemie International Edition, 56(47), 15113-15117.

Depero, L. E., Marino, A., Allieri, B., Bontempi, E., Sangaletti, L., Casale, C., \& Notaro, M. (2000). Morphology and microstructural properties of $\mathrm{TiO}_{2}$ nanopowders doped with trivalent $\mathrm{Al}$ and Ga cations. Journal of Materials Research, 15(10), 2080-2086.

Di Nunzio, P. E., \& Martelli, S. (2006). Coagulation and aggregation model of silicon nanoparticles from laser pyrolysis. Aerosol Science and Technology, 40(9), 724-734.

Dinetz, S. F., Bird, E. J., Wagner, R. L., \& Fountain, A. W., III. (2002). A comparative study of the gaseous products generated by thermal and ultra-violet laser pyrolyses of the polyimide PMDAODA. Journal of Analytical and Applied Pyrolysis, 63(2), 241-249.

Dohčević-Mitrović, Z. D., Milutinović, A., Popović, D., VasiljevićRadović, D., \& Popović, Z. V. (2006). Variable energy gap of SiCN nanopowders. Applied Physics A, 84(1), 197-202.

Dumitrache, F., Morjan, I., Fleaca, C., Badoi, A., Manda, G., Pop, S., Marta, D. S., Huminic, G., Huminic, A., Vekas, L., \& Daia, C. (2015). Highly magnetic $\mathrm{Fe}_{2} \mathrm{O}_{3}$ nanoparticles synthesized by laser pyrolysis used for biological and heat transfer applications. Applied Surface Science, 336, 297-303.

Dumitrache, F., Morjan, I., Alexandrescu, R., Ciupina, V., Prodan, G., Voicu, I., Fleaca, C., Albu, L., Savoiu, M., Sandu, I., \& Popovici, E. (2005). Iron-iron oxide core-shell nanoparticles synthesized by laser pyrolysis followed by superficial oxidation. Applied Surface Science, 247(1-4), 25-31.

Dumitrache, F., Morjan, I. P., Dutu, E., Morjan, I., Fleaca, C. T., Scarisoreanu, M., Ilie, A., Dumitru, M., Mihailescu, C., Smarandache, A., \& Prodan, G. (2019). Zn/F-doped tin oxide nanoparticles synthesized by laser pyrolysis: Structural and optical properties. Beilstein Journal of Nanotechnology, 10(1), 9-21.

Dumitrache, F. V., Ciupina, V., Morjan, I., Alexandrescu, R., Voicu, I., Soare, I., Albu, L., Morjan, R., \& Prodan, G. (2004, October). Carbon-encapsulated iron nanoparticles prepared by laser pyrolysis: characterization and catalyzers for carbon nanotubes and nanofibers. In Nanoengineering: Fabrication, properties, optics, and devices (Vol. 5515, pp. 244-251). International Society for Optics and Photonics.

Duty, C., Johnson, R., Bondi, S., \& Lackey, W. J. (2003). Pyrolytic laser CVD of boron nitride and molybdenum. Chemical Vapor Deposition, 9(6), 298-301.

Ealias, A. M., \& Saravanakumar, M. P. (2017, November). A review on the classification, characterisation, synthesis of nanoparticles and their application. In IOP conference series: Materials science and engineering (Vol. 263, p. 032019).

Erogbogbo, F., Yong, K. T., Roy, I., Hu, R., Law, W. C., Zhao, W., Ding, H., Wu, F., Kumar, R., Swihart, M. T., \& Prasad, P. N. (2011). In vivo targeted cancer imaging, sentinel lymph node mapping and multi-channel imaging with biocompatible silicon nanocrystals. ACS Nano, 5(1), 413-423.

Escamilla-Pérez, A. M., Roland, A., Giraud, S., Guiraud, C., Virieux, H., Demoulin, K., Oudart, Y., Louvain, N., \& Monconduit, L. (2019). Pitch-based carbon/nano-silicon composite, an efficient anode for Li-ion batteries. RSC Advances, 9(19), 10546-10553.

Fa, L., Mei, Z. D., Hua, Z., \& Wancheng, Z. (2006). Dielectric and mechanical properties of hot-pressed $\mathrm{SiCN} / \mathrm{Si}_{3} \mathrm{~N}_{4}$ composites. Journal of Electroceramics, 17(1), 83-86.

Falconieri, M., D’Amato, R., Fabbri, F., Carpanese, M., \& Borsella, E. (2009). Two-photon excitation of luminescence in pyrolytic silicon nanocrystals. Physica E: Low-Dimensional Systems and Nanostructures, 41(6), 951-954.

Folmer, O. F., Jr., \& Azarraga, L. V. (1969). A laser pyrolysis apparatus for gas chromatography. Journal of Chromatographic Science, $7(11), 665-670$.

Figgemeier, E., Kylberg, W., Constable, E., Scarisoreanu, M., Alexandrescu, R., Morjan, I., Soare, I., Birjega, R., Popovici, E., Fleaca, C., Gavrila-Florescu, L., \& Prodan, G. (2007). Titanium dioxide nanoparticles prepared by laser pyrolysis: Synthesis and photocatalytic properties. Applied Surface Science, 254(4), 1037-1041.

Fleaca, C. T., Scarisoreanu, M., Morjan, I., Luculescu, C., Niculescu, A. M., Badoi, A., Vasile, E., \& Kovacs, G. (2015a). Laser oxidative pyrolysis synthesis and annealing of $\mathrm{TiO}_{2}$ nanoparticles embedded in carbon-silica shells/matrix. Applied Surface Science, 336, 226-233.

Fleaca, C., Morjan, I., Dumitrache, F., Niculescu, A., Badoi, A., Luculescu, C., Vasile, E., Prodan, G., \& Vekas, L. (2015b). Sulfidized $\mathrm{Fe}-\mathrm{C}$ nanocomposite powders produced by one-step laser pyrolysis technique. Optoelectronics and Advanced Materials-Rapid Communications, 9(7-8), 933-936.

Fleaca, C. T., Scarisoreanu, M., Morjan, I., Alexandrescu, R., Dumitrache, F., Luculescu, C., Morjan, I. P., Birjega, R., Niculescu, A.-M., Filoti, G., Kuncser, V., Vasile, E., Danciu, V., \& Popa, M. (2014). Recent progress in the synthesis of magnetic titania/ironbased, composite nanoparticles manufactured by laser pyrolysis. Applied Surface Science, 302, 198-204.

Fleaca, C. T., Dumitrache, F., Morjan, I., Alexandrescu, R., Luculescu, C., Niculescu, A., Vasile, E., \& Kuncser, V. (2013). Novel Fe@ $\mathrm{C}-\mathrm{TiO}_{2}$ and $\mathrm{Fe} @ \mathrm{C}-\mathrm{SiO}_{2}$ water-dispersible magnetic nanocomposites. Applied Surface Science, 278, 284-288.

Fleaca, C., Dumitrache, F., Dutu, E., Luculescu, C., Niculescu, A. M., Ilie, A., \& Vasile, E. (2016). One step synthesis of tin-carbon core-shell nanoparticles using laser pyrolysis technique. University Politehnica of Bucharest Scientific Bulletin Series B-Chemistry and Materials Science, 78(2), 43-56.

Florescu, L. G., Fleaca, C., Voicu, I., Morjan, I., Stamatin, L., \& Stamatin, I. (2007). The effect of the nanocarbon structures from laser pyrolysis on microorganisms evolution. Applied Surface Science, 253(19), 7729-7732.

Gadallah, K. A. K., Mutschke, H., \& Jäger, C. (2013). Analogs of solid nanoparticles as precursors of aromatic hydrocarbons. Astronomy \& Astrophysics, 554, A12.

Galvez, A., Herlin-Boime, N., Reynaud, C., Clinard, C., \& Rouzaud, J. N. (2002). Carbon nanoparticles from laser pyrolysis. Carbon, 40(15), 2775-2789.

Gavrila-Florescu, L., Morjan, I., Popovici, E., Sandu, I., Voicu, I., Dinca, I., Stefan, A., Serghie, C., Dumitrache, L., Nistor, C., Stefan, V., Serban, S., Donescu, D., Prodan, G., \& Ciupina, V. (2007). Laser-synthesized carbon nanopowders for nanoscale 
reinforced hybrid composites. Materials Science and Engineering: C, 27(5-8), 1010-1014.

Greenwood, P. F., Van Heemst, J. D., Guthrie, E. A., \& Hatcher, P. G. (2002). Laser micropyrolysis GC-MS of lignin. Journal of Analytical and Applied Pyrolysis, 62(2), 365-373.

Gao, D., Parida, K., \& Lee, P. S. (2019). Emerging soft conductors for bioelectronic interfaces. Advanced Functional Materials, 1907184.

Gavrila-Florescu, L., Dumitrache, F., Balas, M., Fleaca, C. T., Scarisoreanu, M., Morjan, I. P., Dutu, E., Ilie, A., Banici, A.-M., Locovei, C., \& Prodan, G. (2017). Synthesis of Fe-based core@ $\mathrm{ZnO}$ shell nanopowders by laser pyrolysis for biomedical applications. Applied Physics A, 123(12), 802.

Gilmour, J. D., Holland, G., Verchovsky, A. B., Fisenko, A. V., Crowther, S. A., \& Turner, G. (2016). Xenon and iodine reveal multiple distinct exotic xenon components in Efremovka "nanodiamonds." Geochimica Et Cosmochimica Acta, 177, 78-93.

Govender, M., Mwakikunga, B. W., Machatine, A. G. J., \& Kunert, H. W. (2014). Electrical and optical properties of mixed phase tungsten trioxide films grown by laser pyrolysis. Physica Status Solidi (c), 11(2), 349-354.

Govender, M., Shikwambana, L., Mwakikunga, B. W., Sideras-Haddad, E., Erasmus, R. M., \& Forbes, A. (2011). Formation of tungsten oxide nanostructures by laser pyrolysis: Stars, fibres and spheres. Nanoscale Research Letters, 6(1), 1-8.

Greenwood, P. F. (2011). Lasers used in analytical micropyrolysis. Journal of Analytical and Applied Pyrolysis, 92(2), 426-429.

Grimes, C. A., Qian, D., Dickey, E. C., Allen, J. L., \& Eklund, P. C. (2000). Laser pyrolysis fabrication of ferromagnetic $\gamma^{\prime}-\mathrm{Fe}_{4} \mathrm{~N}$ and $\mathrm{FeC}$ nanoparticles. Journal of Applied Physics, 87(9), 5642-5644.

Gueunier-Farret, M. E., Kleider, J. P., Voigt, F., Brüggemann, R., Bauer, G. H., Huisken, F., \& Ledoux, G. (2006). Transport properties and defects in silicon nanoparticles and effect of embedding in amorphous silicon layers. Journal of Non-Crystalline Solids, 352(9-20), 1101-1104.

Guerrero, G. R., Sevilla, L., \& Soriano, C. (2015). Laser and pyrolysis removal of fluorinated ethylene propylene thin layers applied on en AW-5251 aluminium substrates. Applied Surface Science, $353,686-692$.

Han, W. Q., \& Zettl, A. (2002). Pyrolysis approach to the synthesis of gallium nitride nanorods. Applied Physics Letters, 80(2), 303-305.

Herlin-Boime, N., Vicens, J., Dufour, C., Ténégal, F., Reynaud, C., \& Rizk, R. (2004). Flame temperature effect on the structure of SiC nanoparticles grown by laser pyrolysis. Journal of Nanoparticle Research, 6(1), 63-70.

Herring, A. M., McKinnon, J. T., Petrick, D. E., Gneshin, K. W., Filley, J., \& McCloskey, B. D. (2003). Detection of reactive intermediates during laser pyrolysis of cellulose char by molecular beam mass spectroscopy, implications for the formation of polycyclic aromatic hydrocarbons. Journal of Analytical and Applied Pyrolysis, 66(1-2), 165-182.

Hofmeister, H., Huisken, F., \& Kohn, B. (1999). Lattice contraction in nanosized silicon particles produced by laser pyrolysis of silane. In The European physical journal D (pp. 137-140). Springer, Berlin.

Horcher, A., Tangermann-Gerk, K., Barroso, G., Schmidt, M., \& Motz, G. (2020). Laser and furnace pyrolyzed organosilazanebased glass/ZrO2 composite coating system-A comparison. Journal of the European Ceramic Society, 40(7), 2642-2651.

Huminic, G., Huminic, A., Dumitrache, F., Fleacă, C., \& Morjan, I. (2020). Study of the thermal conductivity of hybrid nanofluids: Recent research and experimental study. Powder Technology, $367,347-357$.
Huminic, G., Huminic, A., Fleaca, C., Dumitrache, F., \& Morjan, I. (2017). Thermo-physical properties of water based $\mathrm{SiC}$ nanofluids for heat transfer applications. International Communications in Heat and Mass Transfer, 84, 94-101.

Huminic, G., Huminic, A., Fleaca, C., \& Dumitrache, F. (2016). Heat transfer characteristics of a two-phase closed thermosyphons using nanofluids based on sic nanoparticles. International Journal of Heat and Technology, 34, S199-S204.

Huminic, A., Huminic, G., Fleaca, C., Dumitrache, F., \& Morjan, I. (2015). Thermal conductivity, viscosity and surface tension of nanofluids based on FeC nanoparticles. Powder Technology, $284,78-84$.

Huisken, F., Ledoux, G., Guillois, O., \& Reynaud, C. (2002). Lightemitting silicon nanocrystals from laser pyrolysis. Advanced Materials, 14(24), 1861-1865.

Huisken, F., Amans, D., Ledoux, G., Hofmeister, H., Cichos, F., \& Martin, J. (2003). Nanostructuration with visible-light-emitting silicon nanocrystals. New Journal of Physics, 5(1), 10.

Ilie, A. G., Scarisoreanu, M., Dutu, E., Dumitrache, F., Banici, A. M., Fleaca, C. T., Vasile, E., \& Mihailescu, I. (2018). Study of phase development and thermal stability in as synthesized $\mathrm{TiO}_{2}$ nanoparticles by laser pyrolysis: Ethylene uptake and oxygen enrichment. Applied Surface Science, 427, 798-806.

Ilie, A. G., Scarisoareanu, M., Morjan, I., Dutu, E., Badiceanu, M., \& Mihailescu, I. (2017). Principal component analysis of Raman spectra for $\mathrm{TiO} 2$ nanoparticle characterization. Applied Surface Science, 417, 93-103.

Ishikawa, Y., Koshizaki, N., \& Pyatenko, A. (2016). Submicrometersized spherical iron oxide particles fabricated by pulsed laser melting in liquid. Electronics and Communications in Japan, 99(11), 37-42.

Ivan, R., Popescu, C., del Pino, A. P., Yousef, I., Logofatu, C., \& György, E. (2019). Laser-induced synthesis and photocatalytic properties of hybrid organic-inorganic composite layers. Journal of Materials Science, 54(5), 3927-3941.

Jäger, C., Huisken, F., Mutschke, H., Jansa, I. L., \& Henning, T. (2009). Formation of polycyclic aromatic hydrocarbons and carbonaceous solids in gas-phase condensation experiments. The Astrophysical Journal, 696(1), 706.

Jäger, C., Krasnokutski, S., Staicu, A., Huisken, F., Mutschke, H., Henning, T., Poppitz, W., \& Voicu, I. (2006). Identification and spectral properties of polycyclic aromatic hydrocarbons in carbonaceous soot produced by laser pyrolysis. The Astrophysical Journal Supplement Series, 166(2), 557.

Jamkhande, P. G., Ghule, N. W., Bamer, A. H., \& Kalaskar, M. G. (2019). Metal nanoparticles synthesis: An overview on methods of preparation, advantages and disadvantages, and applications. Journal of Drug Delivery Science and Technology, 53, 101174.

Jang, J., Yeom, J. W., Kang, W. K., Haq, M. R., Lu, X., Shin, D., Kim, S. M., \& In, J. B. (2020). Laser pyrolysis of imprinted furan pattern for the precise fabrication of microsupercapacitor electrodes. Micromachines, 11(8), 746.

Jeong, K., Lee, J., Byun, I., Seong, M. J., Park, J., Kim, H. W., Kim, M. J., Kim, J. H., \& Lee, J. (2017). Synthesis of highly conductive cobalt thin films by LCVD at atmospheric pressure. Materials Science in Semiconductor Processing, 68, 245-251.

Kabashin, A. V., Singh, A., Swihart, M. T., Zavestovskaya, I. N., \& Prasad, P. N. (2019). Laser-processed nanosilicon: A multifunctional nanomaterial for energy and healthcare. ACS Nano, 13(9), 9841-9867.

Kassiba, A., Makowska-Janusik, M., Bouclé, J., Bardeau, J. F., Bulou, A., Herlin, N., Mayne, M., \& Armand, X. (2002). Stoichiometry and interface effects on the electronic and optical 
properties of SiC nanoparticles. Diamond and Related Materials, 11(3-6), 1243-1247.

Kawada, Y., Soeda, J., Satozono, H., Ikeda, Y., \& Takahashi, H. (2019). High-transparency polymer-silicon nano-particle composites for broadband anti-reflection of terahertz waves. Applied Physics Express, 12(9), 092004.

Karn, F. S., Friedel, R. A., \& Sharkey, A. G., Jr. (1967). Distribution of gaseous products from laser pyrolysis of coals of various ranks. Carbon, 5(1), 25-32.

Khan, N., Abas, N., \& Kalair, A. (2015). Pulsed and continuous wave $(\mathrm{CW})$ lasers in the oil, gas, coal and ignition industries. Lasers in Engineering (old City Publishing), 30(3/4), 137-157.

Kim, T. H., Song, H. K., \& Kim, S. (2019a). Production of germanium nanoparticles via laser pyrolysis for anode materials of lithium-ion batteries and sodium-ion batteries. Nanotechnology, 30(27), 275603.

Kim, S., Hwang, C., Park, S. Y., Ko, S. J., Park, H., Choi, W. C., Kim, J. B., Kim, D. S., Park, S., Kim, J. Y., \& Song, H. K. (2014). High-yield synthesis of single-crystal silicon nanoparticles as anode materials of lithium ion batteries via photosensitizer-assisted laser pyrolysis. Journal of Materials Chemistry A, 2(42), 18070-18075.

Kim, S., Park, S. Y., Jeong, J., Kim, G. H., Rohani, P., Kim, D. S., Swihart, M. T., \& Kim, J. Y. (2015). Production of pristine, sulfur-coated and silicon-alloyed germanium nanoparticles via laser pyrolysis. Nanotechnology, 26(30), 305703.

Kim, K. Y., Choi, H., Van Tran, C., \& In, J. B. (2019b). Simultaneous densification and nitrogen doping of laser-induced graphene by duplicated pyrolysis for supercapacitor applications. Journal of Power Sources, 441, 227199.

Kim, H. G., Park, M., Kim, H. Y., Kwac, L. K., \& Shin, H. K. (2017). Characterization of pitch prepared from pyrolysis fuel oil via electron beam irradiation. Radiation Physics and Chemistry, $135,127-132$.

Kintz, H., Paquez, X., Sublemontier, O., Leconte, Y., Herlin-Boime, N., \& Reynaud, C. (2015). Synthesis and layering of Si quantum dots $/ \mathrm{SiO}_{2}$ composite films for third generation solar cells. Thin Solid Films, 593, 96-101.

Kobayashi, Y., Shimizu, N., Nagao, D., Watanabe, A., \& Konno, M. (2011). Fabrication of $\mathrm{BaTiO}_{3}-\mathrm{Y}:$ Eu composite micropatterns by combination of laser induced pyrolysis method and nanocrystalline seeding technique. Surface Engineering, 27(6), 410-413.

Kobayashi, Y., Shimizu, N., Nagao, D., Watanabe, A., \& Konno, M. (2010). Fabrication of $\mathrm{BaTiO}_{3}$ micropatterns by a combination of laser-induced pyrolysis method and nano-crystalline seeding technique and their dielectric properties. Journal of Chemical Engineering of Japan, 43(2), 132-139.

Koshida, N., \& Nakamura, T. (2019). Emerging functions of nanostructured porous silicon-With a focus on the emissive properties of photons, electrons, and ultrasound. Frontiers in Chemistry, 7, 273.

Kostecki, R., Song, X., \& Kinoshita, K. (2002). Fabrication of interdigitated carbon structures by laser pyrolysis of photoresist. Electrochemical and Solid State Letters, 5(6), E29.

Krauss, H. J., \& Motz, G. (2002). Laser pyrolysis of polysilazane-a new technique for the generation of ceramic-like coatings and structures. Key Engineering Materials, 206, 467-470.

Kruger, H. J., Focke, W. W., Mhike, W., Taute, A., \& Roberson, A. (2017). Thermal properties of polyethylene flame retarded with expandable graphite and intumescent fire retardant additives. Fire and Materials, 41(6), 573-586.

Kuncser, V. E., Schinteie, G. A., Kuncser, A. C., Leca, A., Scarisoreanu, M., Morjan, I., \& Filoti, G. (2017). Physical mechanisms of exchange coupling effects in nanoparticulate diluted magnetic oxides obtained by laser pyrolysis. The Journal of Physical Chemistry C, 121(16), 9063-9069.

Kushnir, D., \& Sandén, B. A. (2008). Energy requirements of carbon nanoparticle production. Journal of Industrial Ecology, 12(3), $360-375$.

Kuzuya, M., Hirose, K., \& Matsuoka, T. (2002). Laser pyrolysis gas chromatography system using a Q-switched Nd:YAP laser. Bunseki Kagaku (Japan Analyst), 51.

Kwok, K. H., \& Chiu, W. K. (2003). Open-air carbon coatings on fused quartz by laser-induced chemical vapor deposition. Carbon, 41(4), 673-680.

Laguna-Marco, M. A., Piquer, C., Roca, A. G., Boada, R., AndrésVergés, M., Veintemillas-Verdaguer, S., Serna, C. J., Iadecola, A., \& Chaboy, J. (2014). Structural determination of Bi-doped magnetite multifunctional nanoparticles for contrast imaging. Physical Chemistry Chemical Physics, 16(34), 18301-18310.

Leconte, Y., Maskrot, H., Combemale, L., Herlin-Boime, N., \& Reynaud, C. (2007). Application of the laser pyrolysis to the synthesis of $\mathrm{SiC}, \mathrm{TiC}$ and $\mathrm{ZrC}$ pre-ceramics nanopowders. Journal of Analytical and Applied Pyrolysis, 79(1-2), 465-470.

Leconte, Y., Maskrot, H., Herlin-Boime, N., Porterat, D., Reynaud, C., Gierlotka, S., Swiderska-Sroda, A., \& Vicens, J. (2006). TiC nanocrystal formation from carburization of laser-grown $\mathrm{Ti} / \mathrm{O} / \mathrm{C}$ nanopowders for nanostructured ceramics. The Journal of Physical Chemistry B, 110(1), 158-163.

Ledoux, G., Amans, D., Dujardin, C., \& Masenelli-Varlot, K. (2009). Facile and rapid synthesis of highly luminescent nanoparticles via pulsed laser ablation in liquid. Nanotechnology, 20(44), 445605.

Ledoux, G., Gong, J., Huisken, F., Guillois, O., \& Reynaud, C. (2002). Photoluminescence of size-separated silicon nanocrystals: Confirmation of quantum confinement. Applied Physics Letters, $80(25), 4834-4836$.

Ledoux, G., Gong, J., \& Huisken, F. (2001). Effect of passivation and aging on the photoluminescence of silicon nanocrystals. Applied Physics Letters, 79(24), 4028-4030.

Lee, J. H., Kim, S., Kim, J., Hwang, T., \& Lee, J. C. (2013). Characteristics of silicon nanoparticles depending on $\mathrm{H}_{2}$ gas flow during nanoparticle synthesis via $\mathrm{CO}_{2}$ laser pyrolysis. Korean Journal of Materials Research, 23(5), 260-265.

Lee, J. G., Shin, E. J., Pavelka, R. A., Kirchner, M. S., Dounas-Frazer, D., McCloskey, B. D., Petrick, D. E., McKinnon, J. T., \& Herring, A. M. (2008). Effect of metal doping on the initial pyrolysis chemistry of cellulose chars. Energy \& Fuels, 22(4), 2816-2825.

Ledoux, G., Guillois, O., Porterat, D., Reynaud, C., Huisken, F., Kohn, B., \& Paillard, V. (2000). Photoluminescence properties of silicon nanocrystals as a function of their size. Physical Review B, 62(23), 15942.

Lewandowski, W. M., Januszewicz, K., \& Kosakowski, W. (2019). Efficiency and proportions of waste tyre pyrolysis products depending on the reactor type-A review. Journal of Analytical and Applied Pyrolysis, 140, 25-53.

Li, J., Lei, W., Zhang, X., Wang, B., \& Ba, L. (2004). Field emission of vertically-aligned carbon nanotube arrays grown on porous silicon substrate. Solid-State Electronics, 48(12), 2147-2151.

Li, X., He, Y., Talukdar, S. S., \& Swihart, M. T. (2003). Process for preparing macroscopic quantities of brightly photoluminescent silicon nanoparticles with emission spanning the visible spectrum. Langmuir, 19(20), 8490-8496.

Liu, X., Lu, Y., \& Kuzum, D. (2018). High-density porous graphene arrays enable detection and analysis of propagating cortical waves and spirals. Scientific Reports, 8(1), 1-10.

Liu, Y., Zheng, C., Zhou, Y., Yu, Y., Yin, J., \& Liu, Z. (2000). Ignition model of laser-heated single coal particles. Journal of Engineering Thermophysics, 01. 
Lin, T., Liu, X., Zhou, B., Zhan, Z., Cartwright, A. N., \& Swihart, M. T. (2014). A solution-processed UV-sensitive photodiode produced using a new silicon nanocrystal ink. Advanced Functional Materials, 24(38), 6016-6022.

Liu, J., Qiao, Y., Zhang, P., Xue, Y., \& Cai, Z. (2017). Synthesis of $\mathrm{SiC}$ ceramics from polysilazane by laser pyrolysis. Surface and Coatings Technology, 321, 491-495.

Lomello, F., Bonnefont, G., Leconte, Y., Herlin-Boime, N., \& Fantozzi, G. (2012). Processing of nano-SiC ceramics: Densification by SPS and mechanical characterization. Journal of the European Ceramic Society, 32(3), 633-641.

Ma, L. B., Schmidt, T., Guillois, O., \& Huisken, F. (2009). Evolution of photoluminescence properties of $\mathrm{Si}_{1-\mathrm{x}} \mathrm{Ge}_{\mathrm{x}}$ nanocrystals synthesized by laser-induced pyrolysis. Applied Physics Letters, 95(1), 013115.

Malekzadeh, M., Rohani, P., Liu, Y., Raszewski, A., Ghanei, F., \& Swihart, M. T. (2020). Laser pyrolysis synthesis of zinc-containing nanomaterials using low-cost ultrasonic spray delivery of precursors. Powder Technology, 376, 104-112.

Malumbres, A., Martinez, G., Hueso, J. L., Gracia, J., Mallada, R., Ibarra, A., \& Santamaria, J. (2015). Facile production of stable silicon nanoparticles: Laser chemistry coupled to in situ stabilization via room temperature hydrosilylation. Nanoscale, 7(18), 8566-8573.

Malumbres, A., Martínez, G., Mallada, R., Hueso, J. L., BomatíMiguel, O., \& Santamaría, J. (2013). Continuous production of iron-based nanocrystals by laser pyrolysis. Effect of operating variables on size, composition and magnetic response. Nanotechnology, 24(32), 325603.

Marosfói, B. B., Marosi, G., Szabo, A., Vajna, B., \& Szep, A. (2007). Laser pyrolysis micro-spectroscopy for modelling fire-induced degradation of ethylene-vinyl acetate systems. Polymer Degradation and Stability, 92(12), 2231-2238.

Martelli, S., Mancini, A., Giorgi, R., Alexandrescu, R., Cojocaru, S., Crunteanu, A., Voicu, I., Balu, M., \& Morjan, I. (2000). Production of iron-oxide nanoparticles by laser-induced pyrolysis of gaseous precursors. Applied Surface Science, 154, 353-359.

Martin, J., Cichos, F., Huisken, F., \& von Borczyskowski, C. (2008). Electron-phonon coupling and localization of excitons in single silicon nanocrystals. Nano Letters, 8(2), 656-660.

Martinez, G., Malumbres, A., Lopez, A., Mallada, R., Hueso, J. L., \& Santamaria, J. (2018). Laser-assisted production of carbonencapsulated Pt-Co alloy nanoparticles for preferential oxidation of carbon monoxide. Frontiers in Chemistry, 6, 487.

Martins, A. B., Lobato, A., Tasić, N., Perez-Sanz, F. J., Vidinha, P., Paixao, T. R., \& Goncalves, L. M. (2019). Laser-pyrolyzed electrochemical paper-based analytical sensor for sulphite analysis. Electrochemistry Communications, 107, 106541.

Martínez, G., Malumbres, A., Mallada, R., Hueso, J. L., Irusta, S., Bomatí-Miguel, O., \& Santamaría, J. (2012). Use of a polyol liquid collection medium to obtain ultrasmall magnetic nanoparticles by laser pyrolysis. Nanotechnology, 23(42), 425605.

Mas, N., Hueso, J. L., Martinez, G., Madrid, A., Mallada, R., OrtegaLiebana, M. C., Bueno-Alejo, C., \& Santamaria, J. (2020). Laser-driven direct synthesis of carbon nanodots and application as sensitizers for visible-light photocatalysis. Carbon, 156, 453-462.

Maskrot, H., Leconte, Y., Herlin-Boime, N., Reynaud, C., Guelou, E., Pinard, L., Valange, S., Barrault, J., \& Gervais, M. (2006). Synthesis of nanostructured catalysts by laser pyrolysis. Catalysis Today, 116(1), 6-11.

Masyuk, N., Sherin, A., Snytnikov, V. N., \& Snytnikov, V. N. (2018). Effect of infrared laser radiation on gas-phase pyrolysis of ethane. Journal of Analytical and Applied Pyrolysis, 134, 122-129.

Mathews, T., Antony, R. P., Ajikumar, P. K., Chakraborty, S., Dash, S., Tyagi, A. K., \& Robert, B. (2011, November). Fabrication of
$\mathrm{TiO}_{2}$ nanofibers by electrospinning technique. In International conference on nanoscience, engineering and technology (ICONSET 2011) (pp. 540-542). IEEE.

Mejías, R., Costo, R., Roca, A. G., Arias, C. F., Veintemillas-Verdaguer, S., González-Carreño, T., del Puerto Morales, M., Serna, C. J., Mañes, S., \& Barber, D. F. (2008). Cytokine adsorption/ release on uniform magnetic nanoparticles for localized drug delivery. Journal of Controlled Release, 130(2), 168-174.

Melhem, H., Simon, P., Wang, J., Di Bin, C., Ratier, B., Leconte, Y., Herlin-Boime, N., Makowska-Janusik, M., Kassiba, A., \& Boucle, J. (2013). Direct photocurrent generation from nitrogen doped $\mathrm{TiO}_{2}$ electrodes in solid-state dye-sensitized solar cells: Towards optically-active metal oxides for photovoltaic applications. Solar Energy Materials and Solar Cells, 117, 624-631.

Melhem, H., Simon, P., Beouch, L., Goubard, F., Boucharef, M., Di Bin, C., Leconte, Y., Ratier, B., Herlin-Boime, N., \& Bouclé, J. (2011). $\mathrm{TiO}_{2}$ nanocrystals synthesized by laser pyrolysis for the up-scaling of efficient solid-state dye-sensitized solar cells. Advanced Energy Materials, 1(5), 908-916.

Meruva, N. K., Metz, L. A., Goode, S. R., \& Morgan, S. L. (2004) UV laser pyrolysis fast gas chromatography/time-of-flight mass spectrometry for rapid characterization of synthetic polymers: Instrument development. Journal of Analytical and Applied Pyrolysis, 71(1), 313-325.

Metz, L. A., Meruva, N. K., Morgan, S. L., \& Goode, S. R. (2004). UV laser pyrolysis fast gas chromatography/time-of-flight mass spectrometry for rapid characterization of synthetic polymers: Optimization of instrumental parameters. Journal of Analytical and Applied Pyrolysis, 71(1), 327-341.

Minnekhanov, A. A., Konstantinova, E. A., Pustovoy, V. I., \& Kashkarov, P. K. (2017). The influence of the formation and storage conditions of silicon nanoparticles obtained by laser-induced pyrolysis of monosilane on the nature and properties of defects. Technical Physics Letters, 43(5), 424-427.

Morjan, I., Alexandrescu, R., Dumitrache, F., Birjega, R., Fleaca, C., Soare, I., Luculescu, C. R., Filoti, G., Kuncer, V., Vekas, L., Popa, N. C., Prodan, G., \& Ciupina, V. (2010). Iron oxide-based nanoparticles with different mean sizes obtained by the laser pyrolysis: Structural and magnetic properties. Journal of Nanoscience and Nanotechnology, 10(2), 1223-1234.

Morjan, I., Alexandrescu, R., Scarisoreanu, M., Fleaca, C., Dumitrache, F., Soare, I., Popovici, E., Gavrila, L., Vasile, E., Ciupina, V., \& Popa, N. C. (2009). Controlled manufacturing of nanoparticles by the laser pyrolysis: Application to cementite iron carbide. Applied Surface Science, 255(24), 9638-9642.

Morjan, I., Dumitrache, F., Alexandrescu, R., Fleaca, C., Birjega, R., Luculescu, C. R., Soare, I., Dutu, E., Filoti, G., Kuncser, V., Prodan, G., Popa, N. C., \& Vékás, L. (2012). Laser synthesis of magnetic iron-carbon nanocomposites with size dependent properties. Advanced Powder Technology, 23(1), 88-96.

Morjan, I., Voicu, I., Dumitrache, F., Sandu, I., Soare, I., Alexandrescu, R., Vasile, E., Pasuk, I., Brydson, R. M., Daniels, H., $\&$ Rand, B. (2003). Carbon nanopowders from the continuouswave $\mathrm{CO}_{2}$ laser-induced pyrolysis of ethylene. Carbon, 41(15), 2913-2921.

Murakami, H., Kurata, H., \& Kuzuya, M. (2003). Laser pyrolysis gas chromatography system using a pulsed Nd:YAG laser and its analytical performance. Bunseki Kagaku, 52(10), 891-897.

Mwakikunga, B. W., Sideras-Haddad, E., Forbes, A., \& Arendse, C. (2008a). Raman spectroscopy of $\mathrm{WO}_{3}$ nano-wires and thermochromism study of $\mathrm{VO}_{2}$ belts produced by ultrasonic spray and laser pyrolysis techniques. Physica Status Solidi (a), 205(1), $150-154$.

Mwakikunga, B. W., Forbes, A., Sideras-Haddad, E., \& Arendse, C. (2008b). Optimization, yield studies and morphology of $\mathrm{WO}_{3}$ nano-wires synthesized by laser pyrolysis in $\mathrm{C}_{2} \mathrm{H}_{2}$ and $\mathrm{O}_{2}$ 
ambients-Validation of a new growth mechanism. Nanoscale Research Letters, 3(10), 372-380.

Ning, B., Xia, T., Tong, Z. X., \& He, Y. L. (2019). Experimental and numerical studies of tungsten line growth in laser chemical vapor deposition. International Journal of Heat and Mass Transfer, 140, 564-578.

Nurk, G., Vestli, M., Möller, P., Jaaniso, R., Kodu, M., Mändar, H., Romann, T., Kanarbik, R., \& Lust, E. (2015). Mobility of Sr in gadolinia doped ceria barrier layers prepared using spray pyrolysis, pulsed laser deposition and magnetron sputtering methods. Journal of the Electrochemical Society, 163(2), F88.

Orlanducci, S., Valentini, F., Piccirillo, S., Terranova, M. L., Botti, S., Ciardi, R., Rossi, M., \& Palleschi, G. (2004). Chemical/structural characterization of carbon nanoparticles produced by laser pyrolysis and used for nanotube growth. Materials Chemistry and Physics, 87(1), 190-195.

Petcu, S., Cauchetier, M., Armand, X., Voicu, I., \& Alexandrescu, R. (2000). Formation of fullerenes in the laser-pyrolysis of benzene. Combustion and Flame, 122(4), 500-507.

Pignon, B., Maskrot, H., Guyot Ferreol, V., Leconte, Y., Coste, S., Gervais, M., Pouget, T., Reynaud, C., Tranchant, J.-F., \& HerlinBoime, N. (2008). Versatility of laser pyrolysis applied to the synthesis of $\mathrm{TiO}_{2}$ nanoparticles-application to UV attenuation. European Journal of Inorganic Chemistry, 2008(6), 883-889.

Pokorná, D., Urbanová, M., Bastl, Z., Šubrt, J., \& Pola, J. (2004). Laser-induced gas-phase pyrolysis of dimethyl selenium: Chemical deposition of selenium and poly (selenoformaldehyde). Journal of Analytical and Applied Pyrolysis, 71(2), 635-644.

Popovici, E., Dumitrache, F., Morjan, I., Alexandrescu, R., Ciupina, V., Prodan, G., Vekas, L., Bica, D., Marinica, O., \& Vasile, E. (2007). Iron/iron oxides core-shell nanoparticles by laser pyrolysis: Structural characterization and enhanced particle dispersion. Applied Surface Science, 254(4), 1048-1052.

Pourchez, J., Forest, V., Boumahdi, N., Boudard, D., Tomatis, M., Fubini, B., Herlin-Boime, N., Leconte, Y., Guilhot, B., Cottier, M., \& Grosseau, P. (2012). In vitro cellular responses to silicon carbide nanoparticles: Impact of physico-chemical features on pro-inflammatory and pro-oxidative effects. Journal of Nanoparticle Research, 14(10), 1-12.

Pozio, A., Carewska, M., Mura, F., D’Amato, R., Falconieri, M., De Francesco, M., \& Appetecchi, G. B. (2014). Composite anodes based on nanotube titanium oxide from electro-oxidation of Ti metal substrate. Journal of Power Sources, 247, 883-889.

Prati, S., Fuentes, D., Sciutto, G., \& Mazzeo, R. (2014). The use of laser pyrolysis-GC-MS for the analysis of paint cross sections. Journal of Analytical and Applied Pyrolysis, 105, 327-334.

Qi-Chen, Z., Rui-Ting, H., Si-Jia, L., Xin-Xing, L., Fa-Ran, C., Min, Y., Yi-Lei, L., \& Shu-Rong, W. (2017). Fabrication of $\mathrm{Cu}_{2} \mathrm{ZnSnS}_{4}$ thin films by sputtering quaternary compound target and the research of in-situ annealing. Acta Physica Sinica, 66(22).

Qian, M., Zhou, Y. S., Gao, Y., Park, J. B., Feng, T., Huang, S. M., Sun, Z., Jiang, L., \& Lu, Y. F. (2011). Formation of graphene sheets through laser exfoliation of highly ordered pyrolytic graphite. Applied Physics Letters, 98(17), 173108.

Qiao, Y., Zhao, J., Liu, J., \& Huang, K. (2018). Prepare SiTiOC ceramic coatings by laser pyrolysis of titanium organosilicon compound. Ceramics International, 44(7), 7406-7415.

Park, M. J., Jang, S. C., \& Choi, J. H. (2012). A combined crossedbeam and theoretical study of the reaction dynamics of $\mathrm{O}\left({ }^{3} \mathrm{P}\right)+$ $\mathrm{C}_{2} \mathrm{H}_{3} \rightarrow \mathrm{C}_{2} \mathrm{H}_{2}+\mathrm{OH}$ : Analysis of the nascent $\mathrm{OH}$ products with the preferential population of the $\Pi\left(\mathrm{A}^{\prime}\right)$ component. The Journal of Chemical Physics, 137(20), 204311.
Rahimi, R., Ochoa, M., \& Ziaie, B. (2016). Direct laser writing of porous-carbon/silver nanocomposite for flexible electronics. ACS Applied Materials \& Interfaces, 8(26), 16907-16913.

Réau, A., Guizard, B., Canel, J., Galy, J., \& Ténégal, F. (2012). Silicon carbide nanopowders: The parametric study of synthesis by laser pyrolysis. Journal of the American Ceramic Society, 95(1), 153-158.

Reynaud, C., Guillois, O., Herlin-Boime, N., Rouzaud, J. N., Galvez, A., Clinard, C., Balanzat, E., \& Ramillon, J. M. (2001). Optical properties of synthetic carbon nanoparticles as model of cosmic dust. Spectrochimica Acta Part A: Molecular and Biomolecular Spectroscopy, 57(4), 797-814.

Rijckaert, H., Cayado, P., Nast, R., Diez Sierra, J., Erbe, M., López Dominguez, P., Hänisch, J., De Buysser, K., Holzapfel, B., \& Van Driessche, I. (2020). Superconducting $\mathrm{HfO}_{2}-\mathrm{YBa}_{2} \mathrm{Cu}_{3} \mathrm{O}_{7}-$ $\delta$ nanocomposite films deposited using ink-jet printing of colloidal solutions. Coatings, 10(1), 17.

Roberts, N. A., Gonzalez, C. M., Fowlkes, J. D., \& Rack, P. D. (2013). Enhanced by-product desorption via laser assisted electron beam induced deposition of W (CO) 6 with improved conductivity and resolution. Nanotechnology, 24(41), 415301.

Rohani, P. (2018). Boron, boron hyperdoped silicon and silicon nanoparticle synthesis by laser pyrolysis with applications in energy storage. Doctoral dissertation, State University of New York at Buffalo.

Rohani, B., \& Bae, C. (2017). Effect of exhaust gas recirculation (EGR) and multiple injections on diesel soot nano-structure and reactivity. Applied Thermal Engineering, 116, 160-169.

Rufino, B., Mazerat, S., Couvrat, M., Lorrette, C., Maskrot, H., \& Pailler, R. (2011). The effect of particle size on the formation and structure of carbide-derived carbon on $\beta$-SiC nanoparticles by reaction with chlorine. Carbon, 49(9), 3073-3083.

Russell, D. K., \& Yee, A. (2005). Laser pyrolysis studies of $\beta$-diketonate chemical vapour deposition precursors. Part 1 : $\beta$-diketones. New Journal of Chemistry, 29(3), 485-492.

Russo, D., Spreafico, M., \& Precorvi, A. (2020). Discovering new business opportunities with dependent semantic parsers. Computers in Industry, 123, 103330.

Russo, D., Peri, P., \& Spreafico, C. (2019, October). TRIZ applied to waste pyrolysis project in Morocco. In International TRIZ future conference (pp. 295-304). Springer, Cham.

Rybaltovskii, A. O., Bagratashvili, V. N., Ishchenko, A. A., Minaev, N. V., Kononov, N. N., Dorofeev, S. G., Krutikova, A. A., \& Ol'khov, A. A. (2012). Laser-induced effects in Raman spectra of nanocrystalline silicon. Nanotechnologies in Russia, 7(7), 421-427.

Sandu, I. C., Pasuk, I., Morjan, I. G., Voicu, I. N., Alexandrescu, R., Fleaca, C. T., Ciupina, V., Dumitrache, F. V., Soare, I., Ploscaru, M. I., Daniels, H., Westwood, A., \& Rand, B. (2004, October). Soot morphology in laser pyrolysis. In ROMOPTO 2003: Seventh conference on optics (Vol. 5581, pp. 363-370). International Society for Optics and Photonics.

Scarisoreanu, M., Fleaca, C., Morjan, I., Niculescu, A. M., Luculescu, C., Dutu, E., Ilie, A., Morjan, I., Florescu, L. G., Vasile, E., \& Fort, C. I. (2017). High photoactive $\mathrm{TiO}_{2} / \mathrm{SnO}_{2}$ nanocomposites prepared by laser pyrolysis. Applied Surface Science, 418, 491-498.

Scarisoreanu, M., Morjan, R., Alexandrescu, R., Birjega, I., Voicu, C., Fleaca, E., Popovici, I., Soare, L., Gavrila-Florescu, O., Cretu, G., Prodan, V., \& Ciupina, E. F. (2007). Effects of some synthesis parameters on the structure of titania nanoparticles obtained by laser pyrolysis. Applied Surface Science, 253(19), 7908-7911.

Scarisoreanu, M., Ilie, A. G., Goncearenco, E., Banici, A. M., Morjan, I. P., Dutu, E., Tanasa, E., Fort, I., Stan, M., Mihailescu, C. N., \& Fleaca, C. (2020). Ag, Au and Pt decorated $\mathrm{TiO}_{2}$ biocompatible 
nanospheres for UV \& VIS photocatalytic water treatment. Applied Surface Science, 509, 145217.

Scarisoreanu, M., Ilie, A., Dutu, E., Badoi, A., Dumitrache, F., Tanasa, E., Mihailescu, C. N., \& Mihailescu, I. (2019). Direct nanocrystallite size investigation in microstrained mixed phase $\mathrm{TiO}_{2}$ nanoparticles by PCA of Raman spectra. Applied Surface Science, 470, 507-519.

Shimoda, K. (2018). Low-temperature spark plasma sintering of a $\mathrm{SiC}$ nanopowder with a very thin Al-based layer. Journal of Ceramic Science and Technology, 9(4), 411-418.

Schinteie, G., Kuncser, V., Palade, P., Dumitrache, F., Alexandrescu, R., Morjan, I., \& Filoti, G. (2013). Magnetic properties of ironcarbon nanocomposites obtained by laser pyrolysis in specific configurations. Journal of Alloys and Compounds, 564, 27-34.

Sharuddin, S. D. A., Abnisa, F., Daud, W. M. A. W., \& Aroua, M. K. (2016). A review on pyrolysis of plastic wastes. Energy Conversion and Management, 115, 308-326.

Shin, J., Ko, J., Jeong, S., Won, P., Lee, Y., Kim, J., Hong, S., Jeon, N. L., \& Ko, S. H. (2020). Monolithic digital patterning of polydimethylsiloxane with successive laser pyrolysis. Nature Materials, $1-8$

Shamardin, A., Kurbatov, D., Grase, L., Vecstaudža, J., Kaupužs, J., \& Medvids, A. (2019). Quality improvement of CZTS thin films deposited by spray pyrolysis method using pulsed Nd:YAG laser irradiation. Applied Surface Science, 488, 827-835.

Simakin, A. V., Lubnin, E. N., \& Shafeev, G. A. (2000a). Self-limiting of the thickness of diamond-like films deposited in the laser pyrolysis of liquid aromatic hydrocarbons. Quantum Electronics, 30(3), 263.

Simakin, A. V., Obraztsova, E. D., \& Shafeev, G. A. (2000b). Laserinduced carbon deposition from supercritical benzene. Chemical Physics Letters, 332(3-4), 231-235.

Simon, P., Pignon, B., Miao, B., Coste-Leconte, S., Leconte, Y., Marguet, S., Jegou, P., Bouchet-Fabre, B., Reynaud, C., \& HerlinBoime, N. (2010). N-doped titanium monoxide nanoparticles with $\mathrm{TiO}$ rock-salt structure, low energy band gap, and visible light activity. Chemistry of Materials, 22(12), 3704-3711.

Simoni, F., Huxol, A., \& Villmer, F. J. (2021). Improving surface quality in selective laser melting based tool making. Journal of Intelligent Manufacturing, 1-12.

Sourice, J., Bordes, A., Boulineau, A., Alper, J. P., Franger, S., Quinsac, A., Habert, A., Leconte, Y., De Vito, E., Porcher, W., Reynaud, C., Herlin-Boime, N., \& Haon, C. (2016). Core-shell amorphous silicon-carbon nanoparticles for high performance anodes in lithium ion batteries. Journal of Power Sources, 328, 527-535.

Sourice, J., Quinsac, A., Leconte, Y., Sublemontier, O., Porcher, W., Haon, C., Bordes, A., De Vito, E., Boulineau, A., Larbi, S. J. S., Herlin-Boime, N., \& Reynaud, C. (2015). One-step synthesis of $\mathrm{Si} @ \mathrm{C}$ nanoparticles by laser pyrolysis: High-capacity anode material for lithium-ion batteries. ACS Applied Materials \& Interfaces, 7(12), 6637-6644.

Spreafico, C., Russo, D., \& Spreafico, M. (2021). Investigating the evolution of pyrolysis technologies through bibliometric analysis of patents and papers. Journal of Analytical and Applied Pyrolysis, 105021

Stadnichenko, O., Snytnikov, V., Yang, J., \& Matar, O. (2014). CFD modeling of a laser-induced ethane pyrolysis in a wall-less reactor. In APS, H34-010.

Steglich, M., Carpentier, Y., Jäger, C., Huisken, F., Räder, H. J., \& Henning, T. (2012). The smoothness of the interstellar extinction curve in the UV-Comparison with recent laboratory measurements of PAH mixtures. Astronomy \& Astrophysics, 540, A110.

Sublemontier, O., Lacour, F., Leconte, Y., Herlin-Boime, N., \& Reynaud, C. (2009). $\mathrm{CO}_{2}$ laser-driven pyrolysis synthesis of silicon nanocrystals and applications. Journal of Alloys and Compounds, 483(1-2), 499-502.

Sublemontier, O., Kintz, H., Lacour, F., Paquez, X., Maurice, V., Leconte, Y., Porterat, D., Herlin-Boime, N., \& Reynaud, C. (2011). Synthesis and on-line size control of silicon quantum dots. Kona Powder and Particle Journal, 29, 236-250.

Tangermann-Gerk, K., Barroso, G., Weisenseel, B., Greil, P., Fey, T., Schmidt, M., \& Motz, G. (2016). Laser pyrolysis of an organosilazane-based glass $/ \mathrm{ZrO}_{2}$ composite coating system. Materials \& Design, 109, 644-651.

Ténégal, F., Petcu, S., Herlin-Boime, N., Armand, X., Mayne, M., \& Reynaud, C. (2001). Effect of the C/O ratio on the C60 and C70 formation rates in soot synthesised by laser pyrolysis of benzenebased mixtures. Chemical Physics Letters, 335(3-4), 155-162.

Ténégal, F., de la Rocque, A. G., Dufour, G., Sénémaud, C., Doucey, B., Bahloul-Hourlier, D., Goursat, P., Mayne, M., \& Cauchetier, M. (2000). Structural determination of sintered $\mathrm{Si}_{3} \mathrm{~N}_{4} / \mathrm{SiC}$ nanocomposite using the XPS differential charge effect. Journal of Electron Spectroscopy and Related Phenomena, 109(3), 241-248.

Tiliakos, A., Trefilov, A. M., Tanasă, E., Balan, A., \& Stamatin, I. (2020). Laser-induced graphene as the microporous layer in proton exchange membrane fuel cells. Applied Surface Science, $504,144096$.

Tiliakos, A., Trefilov, A. M., Tanasă, E., Balan, A., \& Stamatin, I. (2018). Space-filling supercapacitor carpets: Highly scalable fractal architecture for energy storage. Journal of Power Sources, 384, 145-155.

Tiliakos, A., Ceaus, C., Iordache, S. M., Vasile, E., \& Stamatin, I. (2016). Morphic transitions of nanocarbons via laser pyrolysis of polyimide films. Journal of Analytical and Applied Pyrolysis, 121, 275-286.

Tóth, Z., \& Piglmayer, K. (2004). Formation of complex tungsten-silica microstructures by $\mathrm{Ar}^{+}$laser processing. Electrochemical and Solid State Letters, 7(11), C133.

Vangelatos, Z., Wang, L., \& Grigoropoulos, C. P. (2020). Laser pyrolysis for controlled morphing and chemical modification on 3D microlattices. Journal of Micromechanics and Microengineering, 30(5), 055008.

van't Zand, D. D., Nachev, P., Rosenfeld, R., Wagener, P., Pich, A., Klee, D., \& Barcikowski, S. (2012). Nanocomposite fibre fabrication via in situ monomer grafting and bonding on laser-generated nanoparticles. Journal of Laser Micro Nanoengineering, $7(1), 21$.

Veintemillas-Verdaguer, S., Morales, M. P., \& Serna, C. J. (2001). Effect of the oxidation conditions on the maghemites produced by laser pyrolysis. Applied Organometallic Chemistry, 15(5), 365-372.

Veintemillas-Verdaguer, S., Bomat1, O., Morales, M. P., Di Nunzio, P. E., \& Martelli, S. (2003). Iron ultrafine nanoparticles prepared by aerosol laser pyrolysis. Materials Letters, 57(5-6), 1184-1189.

Veintemillas-Verdaguer, S., Bomat1-Miguel, O., \& Morales, M. P. (2002). Effect of the process conditions on the structural and magnetic properties of $\gamma-\mathrm{Fe}_{2} \mathrm{O}_{3}$ nanoparticles produced by laser pyrolysis. Scripta Materialia, 47(9), 589-593.

Vladimirov, A. G., Korovin, S. B., Minnekhanov, A. A., Orlov, A. N., Pavlov, R. A., Pustovoy, V. I., \& Surkov, A. A. (2014). Synthesis of composite $\mathrm{Si}-\mathrm{B}$ nanoparticles by the laser-induced pyrolysis method. Laser Physics Letters, 11(12), 126002.

Vladimirov, A., Korovin, S., Surkov, A., Kelm, E., \& Pustovoy, V. (2011). Synthesis of luminescent Si nanoparticles using the laserinduced pyrolysis. Laser Physics, 21(4), 830-835.

Wang, K., Endo-Kimura, M., Belchi, R., Zhang, D., Habert, A., Bouclé, J., Ohtani, B., Kowalska, E., \& Herlin-Boime, N. (2019). Carbon/ 
graphene-modified titania with enhanced photocatalytic activity under UV and VIS irradiation. Materials, 12(24), 4158.

Wang, L. P., Leconte, Y., Feng, Z., Wei, C., Zhao, Y., Ma, Q., Xu, W., Bourrioux, S., Azais, P., Srinivasan, M., \& Xu, Z. J. (2017). Novel preparation of $\mathrm{N}$-doped $\mathrm{SnO}_{2}$ nanoparticles via laserassisted pyrolysis: Demonstration of exceptional lithium storage properties. Advanced Materials, 29(6), 1603286.

Wang, J., Lin, Y., Pinault, M., Filoramo, A., Fabert, M., Ratier, B., Bouclé, J., \& Herlin-Boime, N. (2015). Single-step preparation of $\mathrm{TiO}_{2} / \mathrm{MWCNT}$ nanohybrid materials by laser pyrolysis and application to efficient photovoltaic energy conversion. ACS Applied Materials \& Interfaces, 7(1), 51-56.

Watanabe, A., Kobayashi, Y., Konno, M., Yamada, S., \& Miwa, T. (2005). Direct drawing of Ag microwiring by laser-induced pyrolysis of film prepared from liquid-dispersed metal nanoparticles. Japanese Journal of Applied Physics, 44(5L), L740.

Watanabe, A., Tanase, T., Kobayashi, Y., Konno, M., Yamada, S., \& Miwa, T. (2003). Low temperature processing of crystalline lead zirconate titanate (PZT) film and the direct micropatterning by laser-induced pyrolysis of a sol-gel-derived film. Japanese Journal of Applied Physics, 42(7B), L843.

Watanabe, A., Unno, M., Hojo, F., \& Miwa, T. (2002). Spatially selective formation of microcrystalline germanium by laser-induced pyrolysis of organogermanium nanocluster film. Chemistry Letters, 31(7), 662-663.

Wei, D., \& Xu, X. (2012). Laser direct growth of graphene on silicon substrate. Applied Physics Letters, 100(2), 023110.

Weyermann, C. (2019). Emerging approaches in the analysis of inks on questioned documents. In Emerging technologies for the analysis of forensic traces (pp. 157-178). Springer, Cham.

Wilden, J., \& Fischer, G. (2007). Laser synthesis of nanostructured ceramics from liquid precursors. Applied Surface Science, 254(4), 1067-1072.
Xu, H., \& Hu, J. (2017). Modeling of the material removal and heat affected zone formation in CFRP short pulsed laser processing. Applied Mathematical Modelling, 46, 354-364.

Xue, M., Zhan, Z., Zou, M., Zhang, L., \& Zhao, S. (2016). Green synthesis of stable and biocompatible fluorescent carbon dots from peanut shells for multicolor living cell imaging. New Journal of Chemistry, 40(2), 1698-1703.

Yeon, J. H., Park, S. J., Choi, I., \& Choi, M. (2019). Generation of carbon nano-onions by laser irradiation of gaseous hydrocarbons for high durability catalyst support in proton exchange membrane fuel cells. Journal of Industrial and Engineering Chemistry, 80, $65-73$.

Yeon, J., Choi, I., \& Choi, M. (2018, July). Carbon nano-onions synthesized by laser pyrolysis as catalyst support in proton exchange membrane fuel cells. In ECS meeting abstracts (No. 9, p. 549). IOP Publishing.

Yoshioka, H., \& Ishiwatari, R. (2002). Characterization of organic matter generated from Green River shale by infrared laser pyrolysis. Geochemical Journal, 36(1), 73-82.

Zhao, C., Fezzaa, K., Cunningham, R. W., Wen, H., De Carlo, F., Chen, L., Rollett, A. D., \& Sun, T. (2017). Real-time monitoring of laser powder bed fusion process using high-speed X-ray imaging and diffraction. Scientific Reports, 7(1), 1-11.

Zhao, X., Liang, Y., \& Hu, Z. (2001). Structure and magnetic properties of the oxide layers formed on iron nanoparticles. Acta Metallurgica Sinica, 37(6), 633-636.

Zaitsev, A. S., Egorov, R. I., \& Strizhak, P. A. (2018). Light-induced gasification of the coal-processing waste: Possible products and regimes. Fuel, 212, 347-352.

Publisher's Note Springer Nature remains neutral with regard to jurisdictional claims in published maps and institutional affiliations.

\section{Authors and Affiliations}

\section{Christian Spreafico ${ }^{1}\left[\right.$ Davide Russo $^{2}$ (1) $\cdot$ Riccardo Degl'Innocenti $^{3}$ (])}

Christian Spreafico

christian.spreafico@unibg.it

Davide Russo

davide.russo@unibg.it

Riccardo Degl'Innocenti

r.deglinnocenti@lancaster.ac.uk

1 Department of Management, Information and Production Engineering, University of Bergamo, Via Marconi 5, 24044 Dalmine, BG, Italy
2 Department of Management, Information and Production Engineering, University of Bergamo, Via Marconi 5, 24044 Dalmine, BG, Italy

3 Department of Engineering, Lancaster University, Gillow Ave, Bailrigg, Lancaster LA1 4YW, UK 